\title{
20 Years of Research in Microfinance: An Information Management Approach
}

\section{Begoña Gutiérrez-Nieto and Carlos Serrano-Cinca}

In the last 20 years, microfinance has moved from a promise to reality, although with ups and downs. This paper reviews 1,874 papers published from 1997 to 2017 to perform a scientometric analysis of the microfinance field. The literature review is based on bibliometric data: keyword co-occurrence networks and citation networks were exploited for knowledge mapping. Data analysis shows the two research traditions: papers focusing on clients (welfarists) and papers focusing on microfinance entities themselves (institutionalists). Institutionalism, which had little presence in the early research in microfinance, now exhibits great strength. A chronological analysis reveals the evolution of the topics most interesting to researchers: the first stage described the innovations of the microcredit practices and their impact; the second and very expansive stage in which microfinance institutions' peculiarities were analyzed; and nowadays the sector is mature but with negative aspects arising, such as mission drift. The keywords analysis discovers emerging research topics, shows the use of sophisticated techniques, and recognizes an emerging trend of the sector: achieving financial inclusion.

Keywords: microfinance, microcredit, literature review, scientometrics, welfarism, institutionalism.

JEL Classifications: B21, C83.

\author{
CEB Working Paper N 19/005 \\ March 2019
}

Université Libre de Bruxelles - Solvay Brussels School of Economics and Management

Centre Emile Bernheim

ULB CP114/03 50, avenue F.D. Roosevelt 1050 Brussels BELGIUM 


\title{
20 Years of Research in Microfinance: An Information Management Approach
}

\author{
Begoña Gutiérrez-Nieto \\ Department of Accounting and Finance \\ Universidad de Zaragoza, Spain \\ Department of Accounting and Finance, School of Economics and Business Studies, Universidad de \\ Zaragoza Gran Vía 2, 50005 Zaragoza, Spain, bgn@unizar.es \\ Carlos Serrano-Cinca \\ Department of Accounting and Finance \\ Universidad de Zaragoza, Spain
}

\begin{abstract}
In the last 20 years, microfinance has moved from a promise to reality, although with ups and downs. This paper reviews 1,874 papers published from 1997 to 2017 to perform a scientometric analysis of the microfinance field. The literature review is based on bibliometric data: keyword cooccurrence networks and citation networks were exploited for knowledge mapping. Data analysis shows the two research traditions: papers focusing on clients (welfarists) and papers focusing on microfinance entities themselves (institutionalists). Institutionalism, which had little presence in the early research in microfinance, now exhibits great strength. A chronological analysis reveals the evolution of the topics most interesting to researchers: the first stage described the innovations of the microcredit practices and their impact; the second and very expansive stage in which microfinance institutions' peculiarities were analyzed; and nowadays the sector is mature but with negative aspects arising, such as mission drift. The keywords analysis discovers emerging research topics, shows the use of sophisticated techniques, and recognizes an emerging trend of the sector: achieving financial inclusion.
\end{abstract}

Keywords: microfinance, microcredit, literature review, scientometrics, welfarism, institutionalism.

A slightly revised version of the paper is forthcoming in the International Journal of Information Management

\section{ACKNOWLEDGMENTS}

This work was supported by the Spanish Ministry of Education and Science and the European Regional Development Fund [ECO2013-45568-R], and by the Government of Aragon [Ref. S38_17R]. The funding sources had no involvement in the study design; in the collection, analysis, or interpretation of data; in the writing of the report; or in the decision to submit the article for publication. 


\section{Introduction}

Microcredits are small loans intended for financially excluded individuals. The first microcredit experiences have been lost over time, but modern microfinance institutions (MFIs) have their roots in the 1970s in Bangladesh and Bolivia. The bulk of the microfinance scientific literature hardly comprises 20 years, from 1997 to 2017. Starting with a dozen papers per year, there have been hundreds in the last decade. Microfinance is no longer a promise (Morduch, 1999a) but a reality, achieving the financial inclusion of more than one hundred million people every year (Cull and Morduch, 2017), according to Microcredit Summit Campaign data. But nowadays the real impact of microcredit is questioned (Banerjee et al., 2015b), and the sector is not free from problems, such as mission drift (Copestake, 2007), high rates of interest (Morduch, 2000), stock market speculation (Cull et al., 2009), and repayment pressures that may even lead to suicide (Ashta et al., 2015). The aim of this paper is to study the evolution of microfinance research following a scientometric approach. We have analyzed 1,874 papers, performing a keyword co-occurrence analysis and a citation network analysis, to obtain microcredit knowledge maps.

This study analyzes the current status of microfinance research and its main findings, that is, the evolution of microfinance research topics, the unresolved problems and the challenges regarding microfinance; it concludes by identifying emerging research topics. These goals can be accomplished in many ways, for example, by doing a survey among researchers, examining the impressions that are transmitted in recent conferences, or through a traditional literature review. Our paper follows a scientometric approach. Scientometrics is the quantitative study of science (de Solla Price, 1963), and the use of its methodology reduces the traditional literature review approaches' subjectivity bias (Balaid et al., 2016). We used scientometric methods to addresses four research questions. The first is to identify the core knowledge of the microfinance field by performing a keyword co-occurrence analysis (Rodríguez-Bolívar et al., 2018), showing its main findings, the unresolved problems, the current status, and the challenges regarding microfinance. The second seeks to examine the interest that these topics stimulate in the research community over time, finding hot topics for research by analyzing microfinance knowledge maps and co-citation analysis (Aleixandre et al., 2016). Knowledge maps are useful tools for classifying papers, authors, and journals into clusters (Small, 1973), allowing us to make relevant conclusions on the microfinance state of the art. The third research question aims to identify the most relevant articles by exploring citation relations among them, identifying highly cited authors, not only microfinance researchers but also authors who have influenced the area, even if they do not publish microfinance papers. The fourth question focuses on identifying emerging research topics; to this end, we extracted recently published articles and calculated the average publication date of the articles in which the keyword occurs, the number of occurrences of each keyword, and the average number of citations of each keyword. 
Keyword analysis clearly identified three stages, corresponding to the initial period, the boom after the 2006 Nobel Prize awarded to Muhammad Yunus, and the current maturity period. There are two main research lines in microfinance: one analyzing microfinance institutions themselves, called institutionalism, and one analyzing the clients, called welfarism. There is a long-standing debate on the prevalence of institutionalism versus welfarism on development economics (Klein, 1977) and a feeling that institutionalism has gained the development battle (Jameson, 2006). This debate has moved to the microfinance field (Woller and Woodworth, 1999). We have also found a set of homogeneous investigations that do not belong to either of these two research traditions. Many of them are theoretical papers analyzing economic aspects of microcredit, the problems caused by information asymmetry, or the microcredit effects on credit markets and society in general. Knowledge maps from both keywords and citations revealed that while welfarism dominated microfinance research in the early years, institutionalism now shows great strength.

There have been several reviews of microcredit literature, both argumentative and quantitative. Among the first category, Copestake et al. (2016) performed a historical review that focuses on examining microfinance research over time. Brau and Woller (2004) provided a comprehensive review of over 350 articles, addressing the issues of MFI sustainability and management practices, products, services, clientele targeting, regulation, and impact assessment. Cull and Morduch (2017) provided an updated revision; they performed an integrative literature review that described the global landscape of microfinance, discussing both institutional performance and impacts on poverty, and portraying a broader vision for microfinance. In the quantitative category, Duvendack et al. (2011) performed a metastudy of 58 studies, conducting a statistical analysis that assesses the impact of microfinance on the wellbeing of poor people. Van Rooyen et al. (2012) also performed a systematic review of 15 impact studies, looking for evidence of the impacts of microfinance in Africa. Fall et al. (2018) performed a meta-study of 38 studies on the efficiency of microfinance institutions. Hermes and Hudon (2018) accomplished a meta-study of 170 studies on the performance determinants of microfinance institutions. Despite these reviews, there is still a research gap: the shortage of scientometric literature reviews based on the analysis of bibliographic data. Our paper follows this methodological approach. This research method, which has hardly been explored in the microfinance field, performs a keyword co-occurrence analysis and a citation network analysis, which allows for obtaining microcredit knowledge maps and identifying tendencies of microfinance research.

The paper makes several contributions. First, knowledge maps reveal that welfarism and institutionalism perform as independent bodies in the microfinance literature since authors mostly cite authors from their own cluster. Second, we analyzed the number of published papers and their impact for each group. We conducted our analysis by assigning each keyword to a research tradition and counting its number over the years. We found that the percentage of institutionalist keywords has grown from $20.3 \%$ to a current $36.5 \%$, while the percentage of welfarist keywords has fallen from $51.6 \%$ to a 
current $34.2 \%$; but quality research on impact assessment of microcredit is well recognized and these papers are always among the most cited. Third, the analysis of the keywords and the most cited recent papers did identify emerging research topics, including Islamic finance, the preference for sophisticated techniques such as panel data to analyze institutions and randomized trials for impact studies, and a new motto for the sector: achieving financial inclusion.

The paper has the following structure. The next section describes the scientometric analysis. Two subsections explain the keyword co-occurrence and citation network analyses. The following section then analyzes the most influential papers and identifies research trends. Finally, the conclusions are presented.

\section{Bibliometric analysis of microfinance papers}

Bibliometrics and citation analysis have become important methods for information science, as well as exceptional sources of knowledge for many other areas (Gómez-Jáuregui et al., 2014). Numerous studies employ Scientometrics to analyze the conceptual structure of disciplines. Kapoor et al. (2018), for example, applied scientometric tools to synthesize the findings of literature on social media, identifying multiple emergent themes in the existing corpus. They used VOSviewer software for this purpose. VOSviewer focuses on the analysis at an aggregate level, generating knowledge maps pertaining to a discipline (Van Eck \& Waltman, 2017). For that reason, VOSviewer was chosen to develop part of our research. Many researchers have used co-citation analysis to examine the core concerns of a discipline. Shiau et al. (2017) applied co-citation analysis to the field of social networks, finding that strong ties and weak ties, instead of advertisement, were the main factors affecting wordof-mouth. Shiau et al. (2018) used co-citation analysis to explore the core knowledge of Facebook, finding that this social network had gradually spread from personal communications to groups and enterprises.

One way to improve the reporting quality of a systematic review is the use of checklists, because they provide substantial transparency in the selection process of papers in a systematic review (AlEmran et al., 2018). Nowadays, the most widely used set of guidelines to perform a systematic review of the literature is PRISMA, Preferred Reporting Items for Systematic Reviews and Meta-Analyses, by Moher et al. (2009). Zhang and Li (2017) used the PRISMA guidelines to perform a systematic review of studies focusing on human immunodeficiency virus prevention and treatment employing information and communication technologies. They found that randomized controlled clinical trials with adequate sample sizes were needed to test whether any of the approaches followed would be effective. Regarding formal aspects of literature reviews, AlAlwan et al. (2017) argued that it is preferable to use a conceptdriven systematic review approach that examines the literature from the concepts perspective, as presented by all authors, as opposed to an author-driven approach that looks at how individual authors have analyzed multiple concepts in various articles. We follow the first procedure in our paper. 


\subsection{Papers selection}

The three main databases for academic literature and citation indexes are Web of Science, Google Scholar, and Scopus. Harzing and Alakangas (2016) conclude that all of them provide sufficient stability of coverage to be used for detailed cross-disciplinary comparisons. The coverage for Web of Science and Scopus is similar, while Google Scholar includes books, book chapters, software, and publications in journals not included in the former. A simple search for the term microfinance in Google Scholar returns an impressive record of 231,000 results, and 23,700 results if the search is restricted to the field "title." However, Google Scholar does not have a strong quality control process and simply crawls any information that is available on academic-related websites. For this reason, we chose to start the analysis by using Web of Science. A search by the field "theme" was performed (including title, abstract, and keywords) using the keyword microfinance and its variants micro finance, and micro-finance. Other synonyms of microfinance terms commonly used by researchers were also included, such as microcredit, microbank, microsavings, and microinsurance. The following search criteria were entered into the Web of Science database:

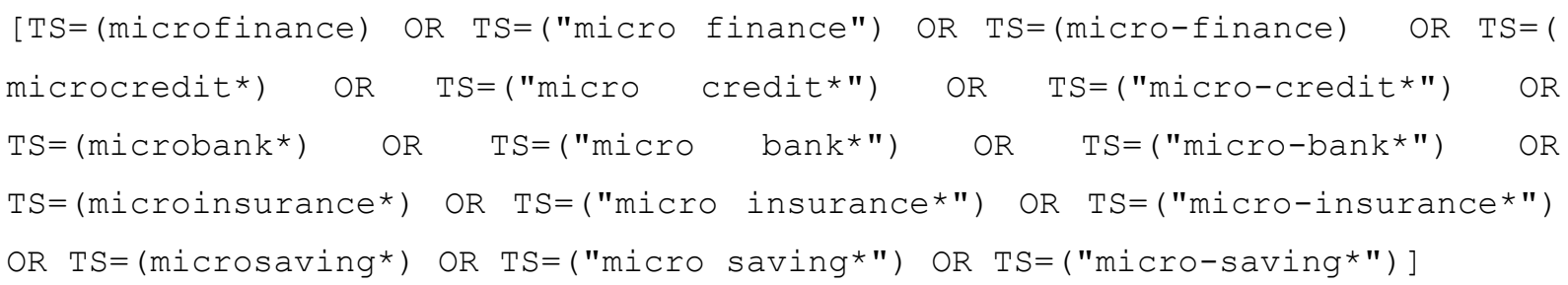

We made the search in the following indexes in the Web of Science collection: SCI-EXPANDED, SSCI, A\&HCI, CPCI-S, CPCI-SSH, and ESCI. We first selected all the years until 2017, but we repeated the same search annually to analyze the time evolution. The search retrieved 2,727 documents. Web of Science does not include books, working papers, or non-indexed journals, so we also searched Google Scholar to ensure that all the relevant documents were included. Google Scholar presents the results by relevance, and we only reviewed the first pages. Some books contributed to making microcredit known; however, journal articles are more commonly used to present academic novelties (Kuhn, 1970), so we did not include them.

Although the selection of articles for any literature review is usually based on the choice of a set of keywords, organized in query structures, and searching them in one or several bibliographic databases, this approach presented many limitations. In our case, in fact, we were not able to identify several highly cited articles on microfinance ${ }^{1}$. Yet many authors have recognized the limitations of this selection procedure (Costa et al., 2016; Dwivedi et al., 2015; Frost \& Choo, 2017; Kapoor et al., 2018; Van Eck and Waltman, 2014; Zahedi et al., 2016). Kapoor et al. (2018) found inconsistencies in the use of keywords in social media research, arguing that a manual search was more appropriate for identifying

\footnotetext{
${ }^{1}$ We acknowledge an anonymous reviewer for this point.
} 
the relevant literature. Zahedi et al. (2016) performed a systematic review of knowledge-sharing challenges in global software development. They emphasized the importance of properly selecting keywords, finding that using only keywords related to "knowledge transfer," and forgetting well-known keywords such "knowledge sharing," limited the search string's ability to retrieve most of the papers. Costa et al. (2016) presented a literature review on the role of information, knowledge and collaboration in decision-making for internationalization processes of small firms, highlighting the importance that governments and institutional supporting agencies may have. They also acknowledged that valuable research articles could have been missed in their review, due to their choice of search strings. Frost and Choo (2017) performed a systematic literature review of the information audit topic. They developed query structures iteratively through trial and error, recognizing that query structures seeking a match for only one conceptual keyword resulted in hundreds of thousands of results, which were unmanageable without a data mining tool.

When selecting keywords organized in query structures does not provide reliable results, the most common solution is following a backward procedure, which means performing an iterative review of the references of an initial set of papers. Henriksen-Bulmer and Jeary (2016) used such a systematic literature review to investigate re-identification attacks; once the papers were identified, the authors conducted a review of the citations of the selected papers. Busalim (2016) not only used a backward search method to trace the citations of the selected studies, but also added a forward references search, which refers to reviewing additional papers that have cited the articles. Ali et al. (2018) applied the backward search method, performing several iterations; in this case, it is called backward snowball technique.

Van Eck and Waltman (2014) developed the CitNetExplorer software to identify publications based on citation relations, starting from a core set of relevant publications. VOSviewer focuses on the analysis at an aggregate level and serves to study the development of a research field over time, while CitNetExplorer focuses on the analysis at the level of individual publications, delineating the literature on a research topic (Van Eck \& Waltman, 2017). Hence, we performed a backward procedure using CitNetExplorer software. First, we took all the articles that included "microfinance," "microcredit" and related terms in the title, abstract or keywords. Then, we performed an iterative review of the references in this initial set of papers. In this manner, a relevant article on microfinance that does not include the selected terms in the title, abstract or keywords list should be identified. Finally, all duplicated documents and papers tangentially analyzing microcredit were excluded. As a result, the number of relevant publications identified from 1997 to 2017 was 1,874, and the number of authors with two or more documents was 445 . Even though the method used has helped to select all relevant papers, there may still be a chance that some relevant ones have been left out, an inherent weakness in any review of literature (Grant \& Booth, 2009). 
Figure 1 displays the time evolution of the number of papers on Web of Science and Google Scholar. The figure shows an exponential growth in the number of published papers, especially from 2007, although a certain fatigue can be perceived in the last few years according to Google Scholar. Two milestones can be highlighted, the declaration by the UN of 2005 as the Year of Microcredit and the 2006 Nobel Peace Prize awarded to Muhammad Yunus. These facts contributed to enhancing interest in microfinance research.

$* * * *$ Figure $1 * * * *$

Figure 2 shows the most cited publications by the core set of relevant microfinance articles, organized by the year in which they appeared. It also shows the citation relations between these publications. Figure 2 was obtained using CitNetExplorer software. The figure allows analyzing the temporal evolution of the most influential publications and identifying some patterns. Pioneering and theoretical works, such as Banerjee et al. (1994) and Varian (1990), are located at the top of the figure, in addition to others such as Stiglitz and Weiss (1981), which influenced microfinance researchers. Many of the theoretical models were developed in this early period. Figure 2 reveals some patterns: For example, it is appreciated that many of the authors dedicated to studying microfinance institutions, e.g., Schreiner (2002), Hartarska (2005), Hermes et al. (2011) and Hudon and Traca (2011), among others, are located in the center left. Many papers that study the impact of microcredit, such as Pitt and Khandker (1998) and Goetz and Gupta (1996), are located on the right of the figure. Finally, a group of papers that relate microfinance to health (Dworkin \& Blankenship, 2009; Kim et al. 2007; Pronyk et al., 2006, 2008) are located on the far right. These results will be analyzed in depth with the other software, VosViewer, to obtain microfinance knowledge maps for the following three periods: 1997-2007, 2008-2012 and 2013-2017.

$* * * *$ Figure $2 * * * *$

Some authors have determined that the distribution function of academic citations adheres to the Pareto principle, or 80/20 rule (Martínez and Anderson, 2015); in other words, typically, 20\% of the articles account for roughly $80 \%$ of citations. In our case, $20 \%$ of the papers accounted for $86.5 \%$ of citations. For the sake of brevity, it is also common to select the "top 5\% papers" considering that almost half of the citations are from them. In our case, $5 \%$ of the papers accounted for exactly $50.9 \%$ of the citations. Those articles in the top 5\% of the rank of citations are defined as excellent or highly cited (Abramo et al., 2014). In our case, 5\% of the 1,874 articles is 93.7, which is rounded to 94. Table 1 shows the 94 most influential papers, according to the number of citations.

$$
* * * * \text { Table } 1 * * * *
$$

It is difficult to discern to what extent a paper is about microfinance. We have calculated a ratio that measures the percentage of citations received from the core set to citations from the Web of Science (see Table 1). This ratio fluctuates between 0 and 1 and tries to measure if the paper is exclusively of 
interest to the microfinance audience or rather to researchers from other areas. We term this the exclusivity ratio. Those papers that are of interest exclusively to microfinance researchers will have a ratio value close to 1 . A ratio value approaching 0 may be a sign that a paper from outside the microfinance field has attracted the attention of microfinance researchers; however, it could also be that a microfinance paper has attracted the interest of researchers from other fields of knowledge. In other words, if the value of the ratio approaches " 1 ," it is a sign that the paper is about microfinance, but if the value of the ratio approaches " 0 ," it can be a non-microfinance paper that interests the microfinance audience or a microfinance paper that interests researchers from other areas. In this last case, its content must be read to elucidate.

In the case analyzed, the average exclusivity ratio is $55.4 \%$, which means that the core set captures more than half the citations that a paper received on average. Five articles (Ashraf et al., 2006; Battilana \& Dorado, 2010; Kabeer, 1999; Pronyk et al., 2006; Stiglitz \& Weiss, 1981) were below 0.2, that is, less than $20 \%$ of their citations came from the core set, so it is worth asking if they are microfinance articles. It seems that Kabeer (1999), presenting a ratio of $6.75 \%$, a paper about women empowerment, provides an example of paper from outside the microfinance field attracting the attention of microfinance researchers. Stiglitz and Weiss (1981), presenting a ratio of 17.28\%, deals with asymmetric information problems in credit markets, and it also has attracted the interest of microfinance researchers. Battilana and Dorado (2010), presenting a ratio of $12.68 \%$, provides an example of a paper clearly about microfinance, but whose focus exceeds the research interest in this field. In this case, the authors developed a new theory to explain the emergence and viability of social enterprises. Ashraf et al. (2006), presenting a ratio of $15.28 \%$, designed a savings product for a Philippine bank. Pronyk et al. (2006), presenting a ratio of $15.84 \%$, is a paper published in The Lancet which received many citations from medical journals. The selection of what papers to be included in Table 1 can be subjective, so we have decided on the most objective criterion: Keep those articles that fall in the top 5\% list of those most cited by the publications on microcredit, displaying the ratio of exclusivity and clarifying that some of these works are not papers on microfinance, but rather publications of interest for microfinance researchers.

The most influential journals are World Development, with 26 papers, followed by the Journal of Development Economics with 11 and the Economic Journal with 7. Table 1 shows the number of citations in Google Scholar and Web of Science documents. However, some papers have an impact on other knowledge fields; for example, those analyzing the relationship between health and microcredit can have an impact on papers in the medical field. So the first column shows the citations received from just the 1,874 microfinance papers. Table 1 also shows the ranking of each paper. The Spearman correlation coefficient between citations by Web of Science and Google Scholar is 0.76 and 0.74 if we only consider the citations by the 1,874 microfinance papers.

\subsection{Keyword co-occurrence networks}


We extracted keywords from each paper to perform a keyword co-occurrence analysis. This technique is a basic scientometric tool to foster systematic reviews of scientific literature, by means of knowledge maps (Radhakrishnan et al., 2017). These maps contain nodes and links; nodes represent keywords while links represent co-occurrences, namely keywords that appear together in many documents. Then, two keywords appear close in the map if they occur together in many documents. The size of the node is proportional to the number of occurrences. We performed a cluster analysis and superimposed its results over each map, visualizing groups of keywords that can be interpreted as research traditions. We used VOSviewer software to obtain the maps (Van Eck and Waltman, 2017). See an example of its usage in Pinho et al. (2018). Figure 3 displays the knowledge maps obtained for the following three periods: 1997-2007, 2008-2012 and 2013-2017. Publications were assigned to clusters by maximizing a quality function, which is a variant of the Girvan-Newman algorithm (Van Eck \& Waltman, 2017).

\section{****Figure 3****}

From analyzing the maps, several patterns arise. First is the growth of the discipline: the first image shows a universe with a small number of topics, while the following stages show an exploding growth in microfinance research. The first map is very homogeneous and reveals welfarism as the main topic. Poverty alleviation and rural or women empowerment are the main keywords. Institutionalism is hardly represented: a couple of keywords, finance and banking, have few occurrences. The second map already shows the emergence of institutionalism on the right side of the map, while welfarism is on the left side. This left cluster contains keywords such as poverty, empowerment, impact, and women. The right cluster includes performance, sustainability, efficiency, and institutions. To sum up, the first issue that arises in a microfinance knowledge map is the trade-off between welfarism and institutionalism. It is even noticeable in the choice of keywords: microcredit is preferred by welfarists while microfinance, naming the institutions, is preferred by institutionalists. The top part of Figure 3 includes keywords outside the previous categories; these keywords belong to theoretical papers of an economic nature, analyzing aspects such as information asymmetry or peer selection. They study many different research topics rather than specializing in one subject, so we have labeled them generalists.

The maps contain several synonyms that can distort the analyses. To ensure a rigorous analysis, the synonyms were grouped into topics, obtaining a microfinance thesaurus. A thesaurus is a type of controlled vocabulary listing synonyms for each entry word. For example, the keywords poverty reduction, poor, poverty alleviation, poverty targeting, urban poverty, bottom of pyramid, and poverty line were replaced by the topic or main term "poverty." According to this grouping, Table 2 displays the more frequent topics in the three periods analyzed, as well as the occurrences of each topic.

$$
\text { **** Table } 2 * * * *
$$


Table 2 shows the topics that always remain, with a structural interest: poverty, women, rural, housing, health, development, impact, and social. It is easy to create a sentence using all these words: microfinance is a development tool trying to alleviate poverty, especially for women in rural areas, with its social impact focused on health and housing, the main issues for researchers. Analyzing the words that appear and disappear in each stage permits the evolution of the research interest to be assessed. In the first stage, many of the papers explained microfinance as banking practices for poor people to help them creating microenterprises, preventing them from using informal finance to solve problems such as lack of food. The focus was placed on group lending methodologies and systems to cope with credit risk, taking as an example the Grameen Bank case. Cost-benefit techniques were used to measure impact. This stage follows a welfarist approach, focused on the client. In the second stage, new topics arise, especially those linked to finance. They follow an institutionalist approach, and their keywords are sustainability, performance, efficiency, governance, and other financial services. On the social side, a keyword emerges: outreach. In the third stage, new trends such as Islamic finance arise. Now microfinance is a tool to achieve financial inclusion, and even the term poor is sometimes replaced by entrepreneurs. Mission drift is a sign of concern.

Many papers include countries as keywords. To assess the role of location, country keywords have been grouped into regions. Asia is the region most studied, with more than half of the papers (60.9\% in the last stage), followed by Africa (23.0\%), Latin America (12.6\%), and the rest of the world (3.4\%). Percentages remain roughly the same in the three stages, except for the rest of the world, which had a $9.4 \%$ in the first stage.

To perform an additional analysis, we classified each relevant keyword into three categories: welfarist, institutionalist, or generalist. We extracted the keywords of each article, as well as the title and abstract. This was done using the BibExcel software (Persson et al., 2009). We identified 1,983 different keywords, classifying each relevant keyword into three categories: welfarist (370), institutionalist (407), or generalist (326), and leaving the remaining terms unassigned (880). In some cases of doubt, we relied on the results of the cluster analysis that assigned each keyword to a group, according to the number of times it appeared in each of them (Figure 3). Many papers can be catalogued as welfarist or institutionalist, but a given paper can deal with both issues; in this case a percentage was assigned according to the number of words of each within them. An example is Navajas et al. (2000). Its keywords are Latin America, Bolivia, microcredit, poverty, outreach, and sustainability. Discarding geographical keywords and the generic word microcredit, poverty is a typical welfarist keyword, while outreach and sustainability are institutionalists. Somehow, this paper could be classified as $66.6 \%$ institutionalist and $33.3 \%$ welfarist. Subsequently, a manual review was made by reading the titles and abstracts of the papers and checking if the classification was sensible or identifying possible misclassifications. Not only does the number of papers matter, but so does their impact. Thus, we took into account the number of citations for each paper and we prorated them according to the keywords' 
percentages. Table 3 shows the welfarism-institutionalism-generalism evolution, according to the number of keywords in each cluster and its impact, measured by the number of citations.

$$
* * * * \text { Table } 3 * * * *
$$

Table 3 shows that welfarist papers dropped from constituting $51.6 \%$ in the first stage to $44.3 \%$ in the second and to $34.2 \%$ in the third, while institutionalist papers increased from $20.3 \%$ to $31.1 \%$ and then to $36.5 \%$ in the three periods, respectively. The third cluster, generalist, remained practically the same throughout $(28.0 \%, 25.5 \%$, and $29.2 \%)$. In terms of citations, Table 3 shows a drop in welfarist papers in a similar proportion as keywords: $49.6 \%$ in the first stage to $43.1 \%$ in the second and to $35.1 \%$ in the third. Institutionalist citations follow the same pattern as keywords: from $22.3 \%$ to $33.2 \%$ to $36.2 \%$. The generalist category comprises $28.1 \%, 23.7 \%$, and $28.6 \%$.

\subsection{Citation networks}

Figure 4 shows the results of a co-citation analysis, performed to cluster a large set of publications based on cited references. The relatedness of the papers in the map is determined by the number of times they are cited together. The map visually displays the influence of microfinance papers because the size of the nodes is proportional to the number of citations received in the microfinance field, that is, from the 1,874 analyzed papers and not the entire Web of Science. The figure at the bottom shows the journals in which the papers were published.

$$
* * * * \text { Figure } 4 * * * *
$$

These results are coherent with the keyword analysis results, clearly showing the three clusters: welfarist papers on the left, institutionalist papers on the right, and generalist papers at the top. The three clusters are very compact because a given paper in a group tends to cite the other papers within its group, rather than papers belonging to other clusters. The most cited paper is Morduch (1999a), a state-of-the art paper occupying a central position in Figure 4 and receiving citations from papers in all the clusters. The papers at the extremes of Figure 4 are the purest exponents of each cluster. Stiglitz and Weiss (1981) is not a microcredit paper, but it is an incontestable reference, especially for theoretical papers. The main welfarist references are Pitt and Khandker (1998) Goetz and Gupta (1996), and Hashemi et al. (1996). The most influential institutionalist papers are Cull et al. (2007), Morduch (2000), Mersland and Strøm (2009), and Hermes et al. (2011). Among the generalist papers, Besley and Coate (1995), Ghatak (1999), Ghatak (2000), Ghatak and Guinnane (1999), Stiglitz (1990) and Sharma and Zeller (1997) can be highlighted. To sum up, this microcredit knowledge map provides a reference guide to the 94 papers that anyone interested in microfinance research should read.

\section{Review of microfinance papers}

Previous keyword co-occurrence and citation analyses contributed to identifying the most relevant issues and the most influential papers. It also built clusters of related authors and topics and 
their evolution. The literature review in this section is based on the most important topics and most cited papers.

\subsection{Main microfinance topics}

Microcredit has been an important approach in development aid and in fighting poverty, trying to provide beneficiaries with the tools to improve their livelihoods. Microfinance has experienced an impressive growth in the last decades of the 20th century. The first academic papers were focused on the innovations provided by microcredit (Adams and Von Pischke, 1992; Yaron, 1992). The innovative lending methodologies for poor borrowers attracted the interest of researchers. These innovations were based on group lending, a mechanism which allows a group of individuals to guarantee loans through a group repayment pledge (Yunus, 2007). Peer pressure increases the probability that the loans will be effectively used for the intended productive purpose (Holvoet, 2005). Cassar et al. (2007) found that socially homogeneous groups consistently perform better than socially heterogeneous groups, although in developed countries group lending does not work well, as highlighted by Schreiner and Woller (2003). However, in some contexts, individual-based contracts have advantages over group lending contracts (Armendáriz and Morduch, 2000). Karlan (2007) found evidence to support that monitoring and enforcement activities do improve group lending outcomes, and that social connections facilitate the monitoring and enforcement of joint liability loan contracts. Wydick (1999) found that borrowing groups can function through a form of social cohesion that may operate independently of previously existing social ties. Factors explaining repayment like gender, group homogeneity, dynamic incentives, and loan characteristics were researched. Bruton et al. (2011) analyzed the causes and consequences of high performance and business failure for microloan recipients. D'espallier et al. (2011) found that women are better credit risks in microfinance than men, whereas Godquin (2004) found no gender difference in repayment performance.

From its beginnings, a number of papers questioned microcredit, warning that credit is, in fact, debt (Adams and Von Pischke, 1992). Yaron (1992) identified some potential problems early on, such as loan defaults, high operating costs, insolvency, and subsidy dependence. Buckley (1997) suggested other necessary and perhaps more appropriate interventions in education, health services, and partaking in civil society. Similarly, Morduch (1999a) claimed that the promise of microfinance has pushed far ahead of the evidence. One year later, Morduch (2000) questioned the win-win proposition, in which both financial institutions and poor clients' profit, affirming that this vision is fully supported by neither logic nor the available empirical evidence. Rankin $(2001,2002)$ affirmed that microfinance programs may in fact serve to defend existing hierarchies of class, caste, and gender without paying attention to the cultural politics of social change. Weber (2002), also skeptical, argued that microcredit was used to facilitate the implementation of financial sector liberalization on a global scale. This skepticism turned into criticism by Rahman (1999) because debt increases tension among household members, produces new forms of dominance over women, and may increase violence in society. It seems that money is only 
one side of the equation: when people lacking financial skills receive a sum of money, for example after winning the lottery, many of them soon go bankrupt (Brickman et al., 1978). Early microfinance researchers warned of the problems associated with flooding people with debt, suggesting the need of a holistic approach to alleviate poverty. Rogaly (1996) presented critical reflections on the use of microcredits in reducing poverty, arguing against microfinance evangelism, noting that a loan becomes debt and the poor are exposed to crisis if expected sources of funds for repayment evaporate.

Hence, authors quickly realized that a key aspect to be analyzed was microcredit impact, that is, its effectiveness. The first impact papers were conceptual, such as Hulme (2000) and Copestake (2007). Some pioneering papers found a positive impact, including Amin et al. (1998), Kabeer (2001) Anderson et al. (2002), McKernan (2002), Mahmud (2003), Matin and Hulme (2003), Schuler and Hashemi (1994), Khandker (2005), Pitt et al. (2006), Pronyk et al. (2006), Kim et al. (2007), Pronyk et al. (2008), and Sanyal (2009). Other papers showed mixed evidence, such as Mosley and Hulme (1998), Coleman (1999), Copestake et al. (2001), Mayoux (2001), Mosley (2001), Amin et al. (2003), Garikipati (2008), Dworkin and Blankenship (2009), Ashraf et al. (2006) and Karlan and Zinman (2010). Dupas and Robinson (2013a) provided strong evidence that a large fraction of female micro-entrepreneurs in rural Kenya face major savings constraints; hence, extending basic banking services could have large effects at a relatively small cost. Giné and Yang (2009) researched credit, insurance and technology adoption in Malawi, finding that when rainfall insurance is bundled with credit, demand for credit falls. Dupas and Robinson (2013b) found that providing individuals with informal savings technologies can substantially increase investment in preventative health. Drexler et al. (2014) found that training to improve knowledge of accounting and finance can have a positive effect on the management practices of small businesses in emerging markets, but the form in which financial literacy training is provided matters.

However, other papers found a negative impact, like McIntosh and Wydick (2005), who warned that over-indebtedness due to asymmetric information could worsen borrowers' situation. Coleman (2006) found that the programs analyzed positively impact cooperative board members, but the impact was insignificant for the other cooperative members. Facing so many contradictory results, Duvendack et al. (2011) performed a meta-study on microcredit impact, revising 74 papers, and found that almost all of them suffered from weak methodologies and inadequate data. They concluded that the circumstances under which microfinance benefits poor people remain unclear. Van Rooyen et al. (2012) performed a systematic review and claimed that the available evidence shows that microfinance both harms and benefits the livelihoods of the poor. The literature review by Cull et al. (2018) shows only modest average impacts on microcredit customers.

A key issue is the design of experiments to measure impact. It is just not sufficient to give small loans to some individuals and to assess several years later that most of them are better off. Perhaps, without microcredit, they could be even better; moreover, the effects on people who do not receive 
microcredit remain unknown. This is why randomized controlled trial methodologies should be used. Given its cost, few papers used this methodology in microfinance. Examples are Karlan and Zinman (2011), who found that microcredit did not generate higher income or subjective well-being, and De Mel et al. (2009), who measured microenterprise profits in Sri Lanka. Banerjee et al. (2013) studied the preparation of microfinance interventions using network data by surveying households. Karlan and Valdivia (2011) analyzed the effect of business training, finding little or no economic evidence in business; however, they observed improvements in business knowledge. Another randomized study is Banerjee et al. (2015a), who found positive impact on profits but no significant changes in health, education, or women's empowerment. Banerjee et al. (2015b) studied the impact of a multifaceted program, finding that it brought about lasting progress for the very poor. Banerjee et al. (2015c) presented six studies on the impact of microcredit, finding a consistent pattern of modestly positive, but not transformative, effect. Despite the methodological adequacy of these randomized studies, their results are only valid in the context in which they were performed, so Karlan and Zinman (2011) encouraged reproducing them in other contexts to have strong evidence of the impact of microcredit.

Another controversial issue concerns institutionalism, with topics like MFIs' sustainability, efficiency, outreach, and the trade-off between outreach and profitability (Cull et al. 2007). Schreiner (2002) proposed a framework for outreach — the social benefits of microfinance — in terms of six aspects: worth, cost, depth, breadth, length, and scope. Ahlin et al. (2011) focused on the impact that the macroeconomic and institutional environment has on the financial and social performance of MFIs, finding that the country context appears to be an important determinant of MFI performance. Battilana and Dorado (2010) dealt with how the focus of MFIs may gradually shift over time from social to financial performance. Not only do the organizational aspects matter, but the accounting aspects do as well. Small loans have high fixed costs, affecting MFIs' profitability. Mersland (2009) studied the cost of ownership in microfinance institutions, finding that the costs of microfinance market contracts are generally higher in shareholder firms than in cooperatives and non-profit organizations, while the costs of ownership-practice are comparatively lower. There are some strategies to improve profitability, such as obtaining donations, increasing interest rates, increasing loan amounts, or gaining efficiency by using innovative technology. Entities such as the Grameen Bank needed subsidies to keep its lending rates low (Morduch, 1999b). Cull et al. (2009) affirmed that subsidies are necessary for institutions with strong social missions. Regarding increasing interest rates, mixed results arise: while Conning (1999) found that sustainable MFIs that target poorer borrowers have to charge higher interest rates, Karlan and Zinman (2008) performed an experiment on borrowers from the same lender, finding that raising rates would have decreased profit and the lender's client base. With respect to increased loan amounts and the risk of mission drift, Navajas et al. (2000) found that MFIs tended not to serve the poorest but rather those near the poverty line. Brau and Woller (2004) provided a comprehensive review of over 350 articles and addressed the issues of microfinance sustainability, products and services, management 
practices, clientele targeting, regulation and policy and impact assessment. Hermes and Lensink (2007) suggested that individual-based MFIs suffer from mission drift, whereas this is less likely for groupbased MFIs. But Mersland and Strøm (2010) found no evidence of mission drift. Using the most recent data from the Microcredit Summit Campaign (Reed, 2015), Cull et al. (2018) noted that the number of the poorest clients fell for the third consecutive year, with both a relative and absolute decline in the orientation toward poor customers, which is a clear sign of mission drift. Finally, a possible way to gain profitability and avoid mission drift is improving efficiency, as suggested by Gutiérrez-Nieto et al. (2007), implying organizational changes and the innovative use of information and communication technologies. Gutiérrez-Nieto et al. (2009) deepened the discourse on using the concept of microfinance social efficiency to measure how well MFIs meet their social responsibilities.

The final research topic is also about institutionalism, focused on aspects such as the governance and legal status of MFIs. Many NGOs have upgraded to regulated MFIs, as studied by Hartarska and Nadolnyak (2007), who concluded that the regulatory involvement does not affect performance in terms of sustainability or outreach. Hermes and Lensink (2011) and Hermes et al. (2011) found convincing evidence that outreach is negatively related to the efficiency of MFIs. Cull et al. (2011) studied the effect of supervision on outreach and profitability, finding that profit-oriented MFIs respond to supervision by maintaining profit rates but reducing outreach to women and costly customers; however, institutions with a weaker commercial focus tend to reduce profitability but maintain outreach. Hartarska (2005) and Mersland and Strøm (2009) studied how the MFI board composition and managerial compensation affect the performance of MFIs. Independent boards may be appropriate for MFIs (Hartarska, 2005), but MFIs have room for improvement in these aspects.

\subsection{Emerging trends}

The analysis of the keywords of the most recent papers allows for identifying the trends in microfinance research. Table 4 shows a set of 20 keywords, along with their average publication year, the number of occurrences, and the average number of citations. The average citations are the number of citations received by the documents in which a keyword occurs. Older papers have had more time to receive citations, so Table 4 displays this indicator both raw and normalized.

$* * * *$ Table $4 * * * *$

Table 4 shows the surge of the term financial inclusion, with 26 occurrences, an average publication year of 2016.5, and 0.9 normalized citations. Another emerging topic is social entrepreneurship; although it has fewer occurrences (19), it has a remarkable number of normalized citations (3.4). Islamic microfinance has a remarkably high 27 occurrences and an average publication year of 2016.1, but the lowest average citations (0.3), indicating that it is a topic the entire microfinance research community lacks interest in. Mission drift is not a new term at all, but it has experienced remarkable growth in the last years, as well as efficiency, outreach, and sustainability, in studies now 
using panel data. Welfarist words are now mature, according to their average publication data, such as impact (2014.2), empowerment (2013.5), rural credit programs (2010.1), and poverty (2013.1). These studies are increasingly using randomized controlled-trials as a research technique. The third cluster, generalist, also becomes mature, with asymmetric information (2012.4) and group lending (2011.8). At the end of Table 4 is Grameen Bank, with an average publication year of 2009.1. Notice also the high use of the term microfinance (534 occurrences) versus microcredit (213 occurrences).

\subsection{Discussion}

As a first research outcome, knowledge maps reveal that welfarism and institutionalism are not bibliographically coupled (Small, 1973), performing as independent bodies of the microfinance literature, since authors mostly cite authors from their own cluster. We consider that increasing the connection between the two different research lines would be beneficial, since it is positive for research lines to learn from each other. For example, impact studies could present institutional information, and vice versa, institutional studies should not lose sight of microfinance clients.

Secondly, after counting the number of published papers in each cluster, we found that the percentage of institutionalist approaches has grown, while the percentage of welfarist approaches has fallen. The process of assigning words to one of the three categories was necessarily subjective, as there is no widely recognized thesaurus with the terms that use each of the three categories. Author bias may therefore arise. We recognize this as a limitation of the paper. However, this fact does not invalidate the trend identified. In a first stage, a large percentage of papers on microcredit were concerned with describing what microcredit was and, especially, its impact on poor people. Institutionalism had little presence. Later, institutionalism increased its presence. In the last stages it seems to have a great progression, according to the method of analysis we have used. In our opinion, this imbalance towards institutionalism is not positive because it means putting the focus of research on entities and not on clients. One reason may be the great variety of issues that arise when analyzing the institutions: corporate governance, mission drift, corporate social responsibility, efficiency and interest rates, whose keywords are visualized in Figure 3. On the contrary, welfarism addresses the same topics-impact, poverty, women's empowerment, health — although they are analyzed with new tools, such as randomized controlled-trial approaches. Another reason may be the wide availability of databases about institutions, including accounting figures, data on governance, ratings, transparency rankings, and all kinds of variables. Databases such as MixMarket, or the data provided by microfinance rating agencies help a great deal in institutionalism research. By contrast, conducting an impact study using randomized controlled trials very often requires performing an expensive field study. This does not mean that it is less interesting to carry out impact studies. This type of research is always well recognized. In fact, a group of highly cited articles on the impact of microcredit can be identified in the lower part of Figure 2; of which two stand out as exceptional: Banerjee et al. (2015a and 2015b), with 1,573 and 688 citations from Google Scholar, respectively, achieved in a very short period of time. We encourage continuing 
research on the impact of microcredit, identifying the conditions under which it works best, i.e., which is the most adequate institution, methodology and environment, thus determining the most favorable breeding ground for microfinance institutions and their clients.

The third research outcome is the identification of emerging research topics, and the surge of "financial inclusion" as a new motto for the sector. We think that although financial inclusion is a motivating goal, it should not be done at any price. Many entities have improved their sustainability indicators, but if this sustainability is achieved by charging high rates to their clients, this results in a financial poverty penalty. In that case, it is desirable that MFIs continue receiving subsidies, as Cull et al. (2009), and Cull et al. (2018) argue. Hudon and Traca (2011) found that subsidies have had a positive impact on microfinance efficiency, but subsidization beyond a certain threshold renders the marginal effect on efficiency negative. Hill (1998) distinguished between shallow sustainability (focusing on the efficient use of resources) and deep sustainability (seeking radical change by re-evaluating goals in relation to higher values and redesigning the systems). This concept, applied in environmental impact studies, can be extrapolated to the microcredit context. Gutiérrez-Nieto et al. (2017) analyzed a sample of Colombian MFIs and identified the set of deep-sustainable institutions, that is, efficient entities, mission-centered, with inclusive and equitable practices, charging fair interest rates and obtaining moderate profits. If we connect the three research outcomes (increasing the connection between welfarism and institutionalism, turning the focus of research towards clients, and aiming for deepsustainable institutions) a policy implication can be derived. We suggest that, being the financial sector one of the most regulated, with many standardized indicators that monitor institutional aspects such as solvency and liquidity, it would be desirable to standardize a set of indicators that monitor institutions' compliance with their social mission.

\section{Summary and conclusions}

Microcredits are small loans for financially excluded individuals. Over time, the term microfinance has become widespread, referring to all kinds of financial services for microcredit recipients. Microfinance experienced a remarkable growth with the creation of Grameen Bank in Bangladesh, in 1976, by Muhammad Yunus. This paper reviews the recent literature on microfinance research has grown exponentially in the last 20 years. The paper has analyzed 1,874 papers from the Web of Science database, from 1997 to 2017, focusing on the top 5\% (94) of most-cited papers. The approach is scientometric, analyzing the keyword co-occurrence and links between citations, to obtain microfinance knowledge maps. The knowledge maps obtained provide a fundamental guide to the publications that any person interested in microfinance research should read.

Knowledge maps obtained from keyword co-occurrence show how in the early years most of the studies were welfarist, focusing on clients. Many of the pioneer researchers were critical of microfinance, warning that money was only one side of the equation. They proposed an integral 
approach, including interventions in education and health services, as well as participation in civil society. In the second stage, one of high growth, many institutionalist papers were published, centered on studying the MFI itself. Our paper identifies a third group of homogeneous studies theoretical in nature. The number of papers in each group was calculated from the papers' keywords. Institutionalism, which had little presence in the early research in microfinance, now exhibits great strength. The data show the important gap between the three clusters, by analyzing both keywords and citations. This is because authors mostly cite other authors from their own cluster. In our opinion, it should be positive that research lines learn from each other. For example, impact studies could present institutional information, and vice versa, institutionalist studies should not lose sight of microfinance clients.

The study identifies, by analyzing the keywords of the most recent papers, future trends in microfinance research. The new startling topics are financial inclusion, social entrepreneurship, and Islamic microfinance. The classic topics remain, such as mission drift, as well as long-standing ones such as efficiency, outreach, and sustainability, with many of them now using panel data models. The welfarist side continues the use of terms such as impact. Some impact studies do not have enough quality to enable robust conclusions, so the trend is the use of randomized controlled trials. What really matters is not only the impact of microcredit but also identifying the conditions under which it works best which is the most adequate institution, methodology, and environment- thus determining the most favorable breeding ground for microfinance institutions and their clients.

\section{References}

Abramo, G., Cicero, T., \& D'Angelo, C. A. (2014). Are the authors of highly cited articles also the most productive ones? Journal of Informetrics, 8(1), 89-97.

Adams, D. W., \& Von Pischke, J. D. (1992). Microenterprise credit programs: Déjà vu. World Development, 20(10), 1463-1470.

Ahlin, C., \& Townsend, R. M. (2007). Using repayment data to test across models of joint liability lending. The Economic Journal, 117(517), F11-F51.

Ahlin, C., Lin, J., \& Maio, M. (2011). Where does microfinance flourish? Microfinance institution performance in macroeconomic context. Journal of Development Economics, 95(2), 105-120.

AlAlwan, A., Rana, N.P., Dwivedi, Y.K., \& Algharabat, R. (2017). Social Media in Marketing: A Review and Analysis of the Existing Literature. Telematics and Informatics, 34(7), 1177-1190.

Aleixandre, J. L., Aleixandre-Tudó, J. L., Bolaños-Pizarro, M., \& Aleixandre-Benavent, R. (2016). Viticulture and oenology scientific research: The Old World versus the New World wine-producing countries. International Journal of Information Management, 36(3), 389-396. 
Al-Emran, M., Mezhuyev, V., Kamaludin, A., \& Shaalan, K. (2018). The impact of knowledge management processes on information systems: A systematic review. International Journal of Information Management, 43, 173-187.

Ali, O., Shrestha, A., Soar, J., \& Wamba, S. F. (2018). Cloud computing-enabled healthcare opportunities, issues, and applications: A systematic review. International Journal of Information Management, 43, 146-158.

Amin, R., Becker, S. \& Bayes, A. (1998). NGO-promoted microcredit programs and women's empowerment in rural Bangladesh: quantitative and qualitative evidence. The Journal of Developing Areas, 32(2), 221-236.

Amin, S., Rai, A. S., \& Topa, G. (2003). Does microcredit reach the poor and vulnerable? Evidence from northern Bangladesh. Journal of Development Economics, 70(1), 59-82.

Anderson, C. L., Locker, L., \& Nugent, R. (2002). Microcredit, social capital, and common pool resources. World Development, 30(1), 95-105.

Armendáriz de Aghion, B., \& Morduch, J. (2000). Microfinance beyond group lending. Economics of Transition, 8(2), 401-420.

Ashraf, N., Karlan, D., \& Yin, W. (2006). Tying Odysseus to the mast: Evidence from a commitment savings product in the Philippines. The Quarterly Journal of Economics, 121(2), 635-672.

Ashta, A., Khan, S., \& Otto, P. (2015). Does microfinance cause or reduce suicides? Policy recommendations for reducing borrower stress. Strategic Change, 24(2), 165-190.

Balaid, A., Rozan, M. Z. A., Hikmi, S. N., \& Memon, J. (2016). Knowledge maps: A systematic literature review and directions for future research. International Journal of Information Management, 36(3), 451-475.

Banerjee, A. V., Besley, T., \& Guinnane, T. W. (1994). Thy neighbor's keeper: The design of a credit cooperative with theory and a test. Quarterly Journal of Economics, 109(2), 491-515.

Banerjee, A., Chandrasekhar, A. G., Duflo, E., \& Jackson, M. O. (2013). The diffusion of microfinance. Science, 341(6144), 1236498.

Banerjee, A., Duflo, E., Glennerster, R., \& Kinnan, C. (2015a). The miracle of microfinance? Evidence from a randomized evaluation. American Economic Journal: Applied Economics, 7(1), 22-53.

Banerjee, A., Duflo, E., Goldberg, N., Karlan, D., Osei, R., Parienté, W., Shapiro, J., Thuysbaert, B., \& Udry, C. (2015b). A multifaceted program causes lasting progress for the very poor: Evidence from six countries. Science, 348(6236), 1260799.

Banerjee, A., Karlan, D., \& Zinman, J. (2015c). Six randomized evaluations of microcredit: Introduction and further steps. American Economic Journal: Applied Economics, 7(1), 1-21. 
Battilana, J., \& Dorado, S. (2010). Building sustainable hybrid organizations: The case of commercial microfinance organizations. Academy of Management Journal, 53(6), 1419-1440.

Besley, T., \& Coate, S. (1995). Group lending, repayment incentives and social collateral. Journal of Development Economics, 46(1), 1-18.

Brau, J. C., \& Woller, G. M. (2004). Microfinance: A comprehensive review of the existing literature and an outline for future research. The Journal of Entrepreneurial Finance, 9(1), 1-27.

Brickman, P., Coates, D., \& Janoff-Bulman, R. (1978). Lottery winners and accident victims: Is happiness relative? Journal of personality and social psychology, 36(8), 917.

Bruton, G. D., Khavul, S., \& Chavez, H. (2011). Microlending in emerging economies: Building a new line of inquiry from the ground up. Journal of International Business Studies, 42(5), 718-739.

Buckley, G. (1997). Microfinance in Africa: Is it either the problem or the solution? World Development, 25(7), 1081-1093.

Busalim, A. H. (2016). Understanding social commerce: A systematic literature review and directions for further research. International Journal of Information Management, 36(6), 1075-1088.

Cassar, A., Crowley, L., \& Wydick, B. (2007). The effect of social capital on group loan repayment: evidence from field experiments. The Economic Journal, 117(517): F85-F106.

Coleman, B. E. (1999). The impact of group lending in Northeast Thailand. Journal of Development Economics, 60(1), 105-141.

Coleman, B. E. (2006). Microfinance in Northeast Thailand: Who benefits and how much? World Development, 34(9), 1612-1638.

Conning, J. (1999). Outreach, sustainability and leverage in monitored and peer-monitored lending. Journal of Development Economics, 60(1), 51-77.

Copestake, J. (2007). Mainstreaming microfinance: Social performance management or mission drift? World Development, 35(10), 1721-1738.

Copestake, J., Bhalotra, S., \& Johnson, S. (2001). Assessing the impact of microcredit: A Zambian case study. Journal of Development Studies, 37(4), 81-100.

Copestake, J., Cabello, M., Goodwin-Groen, R., Gravesteijn, R., \& Humberstone, J. (2016). Towards a plural history of microfinance. Canadian Journal of Development Studies/Revue Canadienne d'études du Développement, 37(3), 279-297.

Costa, E., Soares, A. L., \& de Sousa, J. P. (2016). Information, knowledge and collaboration management in the internationalisation of SMEs: a systematic literature review. International Journal of Information Management, 36(4), 557-569. 
Cull, R. \& Morduch, J. (2017). Microfinance and Economic Development. Manuscript submitted for publication. In Handbook of Finance and Development. Cheltenham, UK: Edward Elgar Publishing.

Cull, R., Demirgüç-Kunt, A., \& Morduch, J. (2009). Microfinance meets the market. Journal of Economic perspectives, 23(1), 167-92.

Cull, R., Demirgüç-Kunt, A., \& Morduch, J. (2007). Financial performance and outreach: A global analysis of leading microbanks. The Economic Journal, 117(517): F107-F133.

Cull, R., Demirgüç-Kunt, A., \& Morduch, J. (2011). Does regulatory supervision curtail microfinance profitability and outreach? World Development, 39(6), 949-965.

Cull, R., Demirgüç-Kunt, A., \& Morduch, J. (2018). The Microfinance Business Model: Enduring Subsidy and Modest Profit. The World Bank Economic Review, 32(2), 221-244.

D’espallier, B., Guérin, I., \& Mersland, R. (2011). Women and repayment in microfinance: A global analysis. World Development, 39(5), 758-772.

De Mel, S., McKenzie, D.J., \& Woodruff, C. (2008). Returns to capital in microenterprises: evidence from a field experiment. Quarterly journal of Economics, 123(4), 1329-1372.

De Mel, S., McKenzie, D. J., \& Woodruff, C. (2009). Measuring microenterprise profits: Must we ask how the sausage is made? Journal of Development Economics, 88(1), 19-31.

de Solla Price, D. J. (1963). Little science, big science. New York: Columbia University Press.

Drexler, A., Fischer, G., \& Schoar, A. (2014). Keeping it simple: Financial literacy and rules of thumb. American Economic Journal: Applied Economics, 6(2), 1-31.

Dupas, P., \& Robinson, J. (2013a). Savings constraints and microenterprise development: Evidence from a field experiment in Kenya. American Economic Journal: Applied Economics, 5(1), 163 92.

Dupas, P., \& Robinson, J. (2013b). Why don't the poor save more? Evidence from health savings experiments. American Economic Review, 103(4), 1138-71.

Duvendack, M., Palmer-Jones, R., Copestake, J.G., Hooper, L., Loke, Y. \& Rao N. (2011). What is the evidence of the impact of microfinance on the well-being of poor people? EPPI-Centre, Social Science Research Unit, Institute of Education, University of London, London.

Dwivedi, Y.K, Kapoor, K.K., \& Chen, H (2015). Social Media Marketing and Advertising. The Marketing Review, 15(3), 289-309

Dworkin, S. L., \& Blankenship, K. (2009). Microfinance and HIV/AIDS prevention: assessing its promise and limitations. AIDS and Behavior, 13(3), 462-469.

Fall, F., Akim, A. M., \& Wassongma, H. (2018). DEA and SFA research on the efficiency of microfinance institutions: A meta-analysis. World Development, 107, 176-188. 
Frost, R. B., \& Choo, C. W. (2017). Revisiting the information audit: A systematic literature review and synthesis. International Journal of Information Management, 37(1), 1380-1390.

Garikipati, S. (2008). The impact of lending to women on household vulnerability and women's empowerment: evidence from India. World Development, 36(12), 2620-2642

Ghatak, M. (1999). Group lending, local information and peer selection. Journal of Development Economics, 60(1), 27-50.

Ghatak, M. (2000). Screening by the company you keep: Joint liability lending and the peer selection effect. The Economic Journal, 110(465), 601-631.

Ghatak, M., \& Guinnane, T. W. (1999). The economics of lending with joint liability: theory and practice. Journal of Development Economics, 60(1), 195-228.

Giné, X., \& Yang, D. (2009). Insurance, credit, and technology adoption: Field experimental evidence from Malawi. Journal of Development Economics, 89(1), 1-11.

Godquin, M. (2004). Microfinance repayment performance in Bangladesh: How to improve the allocation of loans by MFIs. World Development, 32(11), 1909-1926.

Goetz, A. M., \& Gupta, R. S. (1996). Who takes the credit? Gender, power, and control over loan use in rural credit programs in Bangladesh. World Development, 24(1), 45-63.

Gómez-Jáuregui, V., Gómez-Jáuregui, C., Manchado, C. \& Otero, C. (2014). Information management and improvement of citation indices. International Journal of Information Management, 34(2), 257271.

Grant, M. J., \& Booth, A. (2009). A typology of reviews: an analysis of 14 review types and associated methodologies. Health Information \& Libraries Journal, 26(2), 91-108.

Gutierrez-Nieto, B., Serrano-Cinca, C., \& Mar-Molinero, C. (2007). Microfinance institutions and efficiency. Omega, 35(2), 131-142.

Gutiérrez-Nieto, B., Serrano-Cinca, C., \& Mar-Molinero, C. (2009). Social efficiency in microfinance institutions. Journal of the Operational Research Society, 60(1), 104-119.

Gutiérrez-Nieto, B., Serrano-Cinca, C., Fernández, B. C., \& Fuertes-Callén, Y. (2017). Poverty penalty and microfinance. Social Indicators Research, 133(2), 455-475.

Hartarska, V. (2005). Governance and performance of microfinance institutions in Central and Eastern Europe and the newly independent states. World Development, 33(10), 1627-1643.

Hartarska, V., \& Nadolnyak, D. (2007). Do regulated microfinance institutions achieve better sustainability and outreach? Cross-country evidence. Applied Economics, 39(10), 1207-1222.

Harzing, A. W., \& Alakangas, S. (2016). Google Scholar, Scopus and the Web of Science: a longitudinal and cross-disciplinary comparison. Scientometrics, 106(2), 787-804. 
Hashemi, S. M., Schuler, S. R., \& Riley, A. P. (1996). Rural credit programs and women's empowerment in Bangladesh. World Development, 24(4), 635-653.

Henriksen-Bulmer, J., \& Jeary, S. (2016). Re-identification attacks-A systematic literature review. International Journal of Information Management, 36(6), 1184-1192.

Hermes, N., \& Hudon, M. (2018). Determinants of the Performance of Microfinance Institutions: A Systematic Review. Journal of Economic Surveys. Advance online publication doi: $10.1111 /$ joes. 12290

Hermes, N., \& Lensink, R. (2007). The empirics of microfinance: what do we know? The Economic Journal, 117(517): F1-F10.

Hermes, N., \& Lensink, R. (2011). Microfinance: its impact, outreach, and sustainability. World Development, 39(6), 875-881.

Hermes, N., Lensink, R., \& Meesters, A. (2011). Outreach and efficiency of microfinance institutions. World Development, 39(6), 938-948.

Hill, S. B. (1998). Redesigning agroecosystems for environmental sustainability: a deep systems approach. Systems Research and Behavioral Science: The Official Journal of the International Federation for Systems Research, 15(5), 391-402.

Holvoet, N. (2005). The impact of microfinance on decision-making agency: evidence from South India. Development and Change, 36(1), 75-102.

Hudon, M., \& Traca, D. (2011). On the efficiency effects of subsidies in microfinance: An empirical inquiry. World Development, 39(6), 966-973.

Hulme, D. (2000). Impact assessment methodologies for microfinance: theory, experience and better practice. World Development, 28(1), 79-98.

Jameson, K. P. (2006). Has institutionalism won the development debate? Journal of Economic Issues, 40(2), 369-375.

Kabeer, N. (1999). Resources, agency, achievements: Reflections on the measurement of women's empowerment. Development and change, 30(3), 435-464.

Kabeer, N. (2001). Conflicts over credit: re-evaluating the empowerment potential of loans to women in rural Bangladesh. World Development, 29(1), 63-84.

Kapoor, K.K., Tamilmani, K., Rana, N.P., Patil, P., Dwivedi, Y.K. \& Nerur, S. (2018). Advances in Social Media Research: Past, Present and Future. Information Systems Frontiers. 20(3), 531-558.

Karlan, D. (2007). Social connections and group banking. The Economic Journal, 117(517), F52-F84.

Karlan, D., \& Valdivia, M. (2011). Teaching entrepreneurship: Impact of business training on microfinance clients and institutions. Review of Economics and Statistics, 93(2): 510-527. 
Karlan, D., \& Zinman, J. (2008). Credit elasticities in less-developed economies: Implications for microfinance. The American Economic Review, 98(3), 1040-1068.

Karlan, D., \& Zinman, J. (2010). Expanding credit access: Using randomized supply decisions to estimate the impacts. The Review of Financial Studies, 23(1), 433-464.

Karlan, D., \& Zinman, J. (2011). Microcredit in theory and practice: Using randomized credit scoring for impact evaluation. Science, 332(6035), 1278-1284.

Khandker, S. R. (2005). Microfinance and poverty: Evidence using panel data from Bangladesh. The World Bank Economic Review, 19(2), 263-286.

Kim, J. C., Watts, C. H., Hargreaves, J. R., Ndhlovu, L. X., Phetla, G., Morison, L. A., Busza, J., Porter, J. D. H., \& Pronyk, P. (2007). Understanding the impact of a microfinance-based intervention on women's empowerment and the reduction of intimate partner violence in South Africa. American Journal of Public Health, 97(10), 1794-1802.

Klein, P. A. (1977). An institutionalist view of development economics. Journal of Economic Issues, 11(4), 785-807.

Kuhn, T. S. (1970). The Structure of Scientific Revolutions. (2nd enl. Ed). University of Chicago Press.

Mahmud, S. (2003). Actually how empowering is microcredit? Development and Change, 34(4), 577605.

Martínez, R. A., \& Anderson, T. (2015). Are the most highly cited articles the ones that are the most downloaded? A bibliometric study of IRRODL. The International Review of Research in Open and Distributed Learning, 16(3), 18-40.

Matin, I., \& Hulme, D. (2003). Programs for the Poorest: Learning from the IGVGD Program in Bangladesh. World Development, 31(3), 647-665.

Mayoux, L. (2001). Tackling the down side: Social capital, women's empowerment and micro-finance in Cameroon. Development and Change, 32(3), 435-464.

McIntosh, C., \& Wydick, B. (2005). Competition and microfinance. Journal of Development Economics, 78(2), 271-298.

McKernan, S. M. (2002). The impact of microcredit programs on self-employment profits: Do noncredit program aspects matter? The Review of Economics and Statistics, 84(1), 93-115.

Mersland, R. (2009). The cost of ownership in microfinance organizations. World Development, 37(2), 469-478.

Mersland, R., \& Strøm, R. Ø. (2009). Performance and governance in microfinance institutions. Journal of Banking \& Finance, 33(4), 662-669.

Mersland, R., \& Strøm, R. Ø. (2010). Microfinance mission drift? World Development, 38(1), 28-36. 
Moher, D., Liberati, A., Tetzlaff, J., \& Altman, D. G. (2009). Preferred reporting items for systematic reviews and meta-analyses: the PRISMA statement. Annals of internal medicine, 151(4), 264269.

Morduch, J. (1999a). The microfinance promise. Journal of Economic Literature, 37(4), 1569-1614.

Morduch, J. (1999b). The role of subsidies in microfinance: evidence from the Grameen Bank. Journal of Development Economics, 60(1), 229-248.

Morduch, J. (2000). The microfinance schism. World Development, 28(4), 617-629.

Mosley, P. (2001). Microfinance and poverty in Bolivia. Journal of Development Studies, 37(4), 101132.

Mosley, P., \& Hulme, D. (1998). Microenterprise finance: is there a conflict between growth and poverty alleviation? World Development, 26(5), 783-790.

Navajas, S., Schreiner, M., Meyer, R. L., Gonzalez-Vega, C., \& Rodriguez-Meza, J. (2000). Microcredit and the Poorest of the Poor: Theory and Evidence from Bolivia. World Development, 28(2), 333346.

Persson, O., Danell, R., \& Schneider, J. W. (2009). How to use Bibexcel for various types of bibliometric analysis. Celebrating scholarly communication studies: A Festschrift for Olle Persson at his 60th Birthday, 5, 9-24.

Pinho, C., Franco, M., \& Mendes, L. (2018). Web portals as tools to support information management in higher education institutions: A systematic literature review. International Journal of Information Management, 41, 80-92.

Pitt, M. M., \& Khandker, S. R. (1998). The impact of group-based credit programs on poor households in Bangladesh: Does the gender of participants matter? Journal of Political Economy, 106(5), 958996.

Pitt, M. M., Khandker, S. R., \& Cartwright, J. (2006). Empowering women with micro finance: Evidence from Bangladesh. Economic Development and Cultural Change, 54(4), 791-831.

Pronyk, P. M., Hargreaves, J. R., Kim, J. C., Morison, L. A., Phetla, G., Watts, C., ... \& Porter, J. D. (2006). Effect of a structural intervention for the prevention of intimate-partner violence and HIV in rural South Africa: a cluster randomised trial. The Lancet, 368(9551), 1973-1983.

Pronyk, P. M., Kim, J. C., Abramsky, T., Phetla, G., Hargreaves, J. R., Morison, L. A., Watts, C., Busza, J., \& Porter, J. D. (2008). A combined microfinance and training intervention can reduce HIV risk behaviour in young female participants. Aids, 22(13), 1659-1665.

Quayes, S. (2012). Depth of outreach and financial sustainability of microfinance institutions. Applied Economics, 44(26), 3421-3433. 
Radhakrishnan, S., Erbis, S., Isaacs, J. A., \& Kamarthi, S. (2017). Novel keyword co-occurrence network-based methods to foster systematic reviews of scientific literature. PloS one, 12(3), e0172778.

Rahman, A. (1999). Micro-credit initiatives for equitable and sustainable development: Who pays? World Development, 27(1), 67-82.

Rankin, K. N. (2001). Governing development: neoliberalism, microcredit, and rational economic woman. Economy and Society, 30(1), 18-37.

Rankin, K. N. (2002). Social capital, microfinance, and the politics of development. Feminist Economics, 8(1), 1-24.

Reed, L. R. (2015). Mapping Pathways out of Poverty: The State of the Microcredit Summit Campaign Report. Washington D.C.

Rodríguez-Bolívar, M.P., Alcaide-Muñoz, L. Cobo, M.J. (2018). Analyzing the scientific evolution and impact of e-Participation research in JCR journals using science mapping. International Journal of Information Management, 40, 111-119.

Rogaly, B. (1996). Micro-finance evangelism,'destitute women', and the hard selling of a new antipoverty formula. Development in Practice, 6(2), 100-112.

Sanyal, P. (2009). From credit to collective action: The role of microfinance in promoting women's social capital and normative influence. American Sociological Review, 74(4), 529-550.

Schreiner, M. (2002). Aspects of outreach: A framework for discussion of the social benefits of microfinance. Journal of International Development, 14(5), 591-603.

Schreiner, M., \& Woller, G. (2003). Microenterprise development programs in the United States and in the developing world. World Development, 31(9), 1567-1580.

Schuler, S. R., \& Hashemi, S. M. (1994). Credit programs, women's empowerment, and contraceptive use in rural Bangladesh. Studies in family planning, 65-76.

Sharma, M., \& Zeller, M. (1997). Repayment performance in group-based credit programs in Bangladesh: An empirical analysis. World Development, 25(10), 1731-1742.

Shiau, W.-L., Dwivedi, Y.K., \& Lai, H.-H. (2018). Examining the core knowledge on Facebook. International Journal of Information Management, 43, 52-63.

Shiau, W.-L., Dwivedi, Y.K., \& Yang, H.-S. (2017). Co-citation and cluster analyses of extant literature on social networks. International Journal of Information Management, 37(5), 390-399.

Small, H. (1973). Co-citation in the scientific literature: A new measure of the relationship between two documents. Journal of the Association for Information Science and Technology, 24(4), 265-269. 
Stiglitz, J. E. (1990). Peer monitoring and credit markets. The World Bank Economic Review, 4(3), 351366.

Stiglitz, J. E., \& Weiss, A. (1981). Credit rationing in markets with imperfect information. The American Economic Review, 71(3), 393-410.

Van Eck, N. J., \& Waltman, L. (2014). CitNetExplorer: A new software tool for analyzing and visualizing citation networks. Journal of Informetrics, 8(4), 802-823.

Van Eck, N. J., \& Waltman, L. (2017). Citation-based clustering of publications using CitNetExplorer and VOSviewer. Scientometrics, 111(2), 1053-1070.

Van Rooyen, C., Stewart, R., \& De Wet, T. (2012). The impact of microfinance in sub-Saharan Africa: a systematic review of the evidence. World Development, 40(11), 2249-2262.

Varian, H. R. (1990). Monitoring agents with other agents. Journal of Institutional and Theoretical Economics, 153-174.

Weber, H. (2002). The imposition of a global development architecture: The example of microcredit. Review of International Studies, 28(3), 537-555.

Woller, G., \& Woodworth, W. (1999). Where to microfinance? International Journal of Economic Development, 1(1), 29-64.

Wydick, B. (1999). Can social cohesion be harnessed to repair market failures? Evidence from group lending in Guatemala. The Economic Journal, 109(457), 463-475.

Yaron, J. (1992). Assessing Development Finance Institutions; A Public Interest Analysis (No. 174). World Bank.

Yunus, M. (2007). Banker to the Poor. Penguin Books India.

Zahedi, M., Shahin, M., \& Babar, M. A. (2016). A systematic review of knowledge sharing challenges and practices in global software development. International Journal of Information Management, 36(6), 995-1019.

Zhang, Y., \& Li, X. (2017). Uses of information and communication technologies in HIV selfmanagement: A systematic review of global literature. International Journal of Information Management, 37(2), 75-83. 

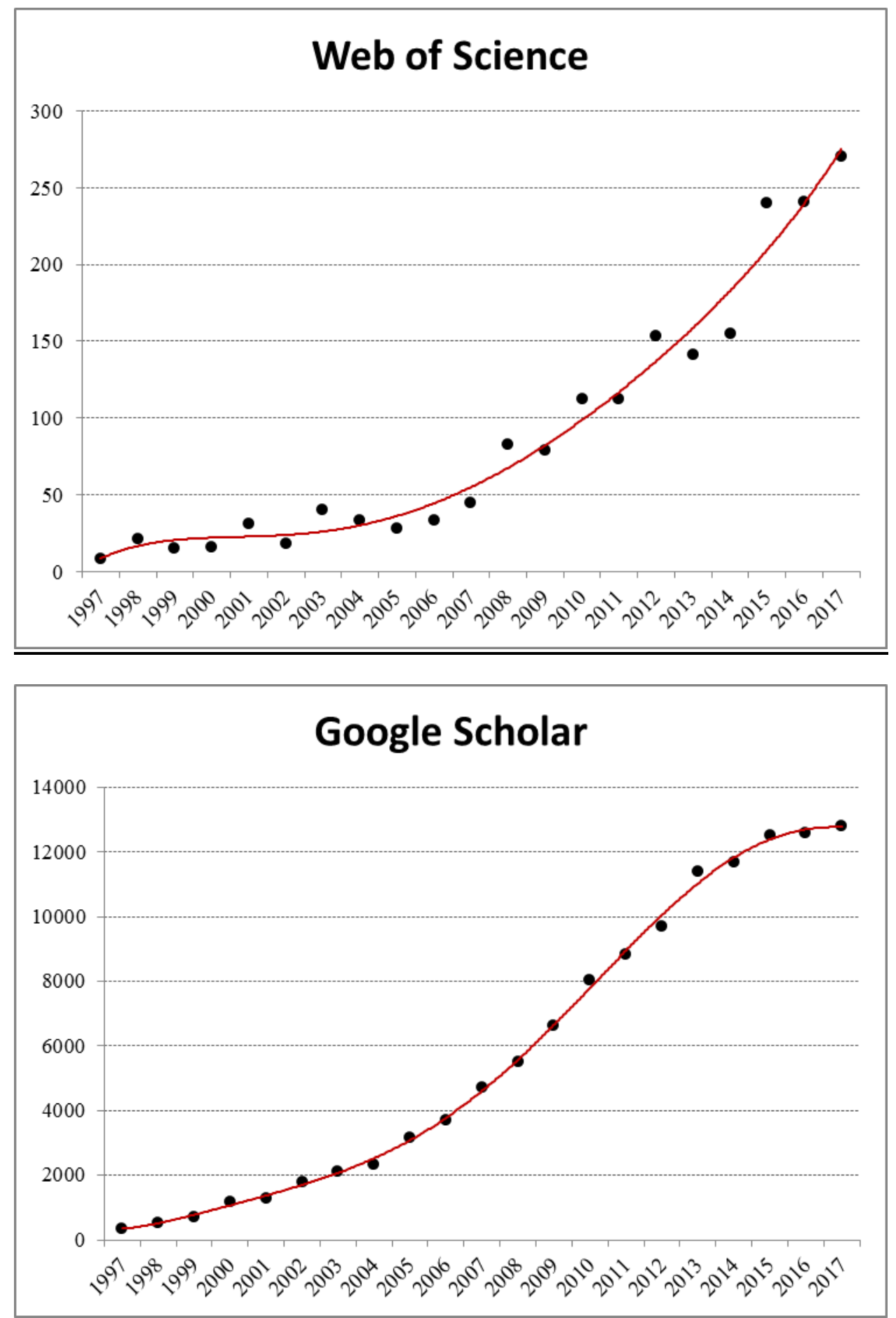

Figure 1. The number of publications on microfinance per year. Source: Web of Science and Google Scholar. 


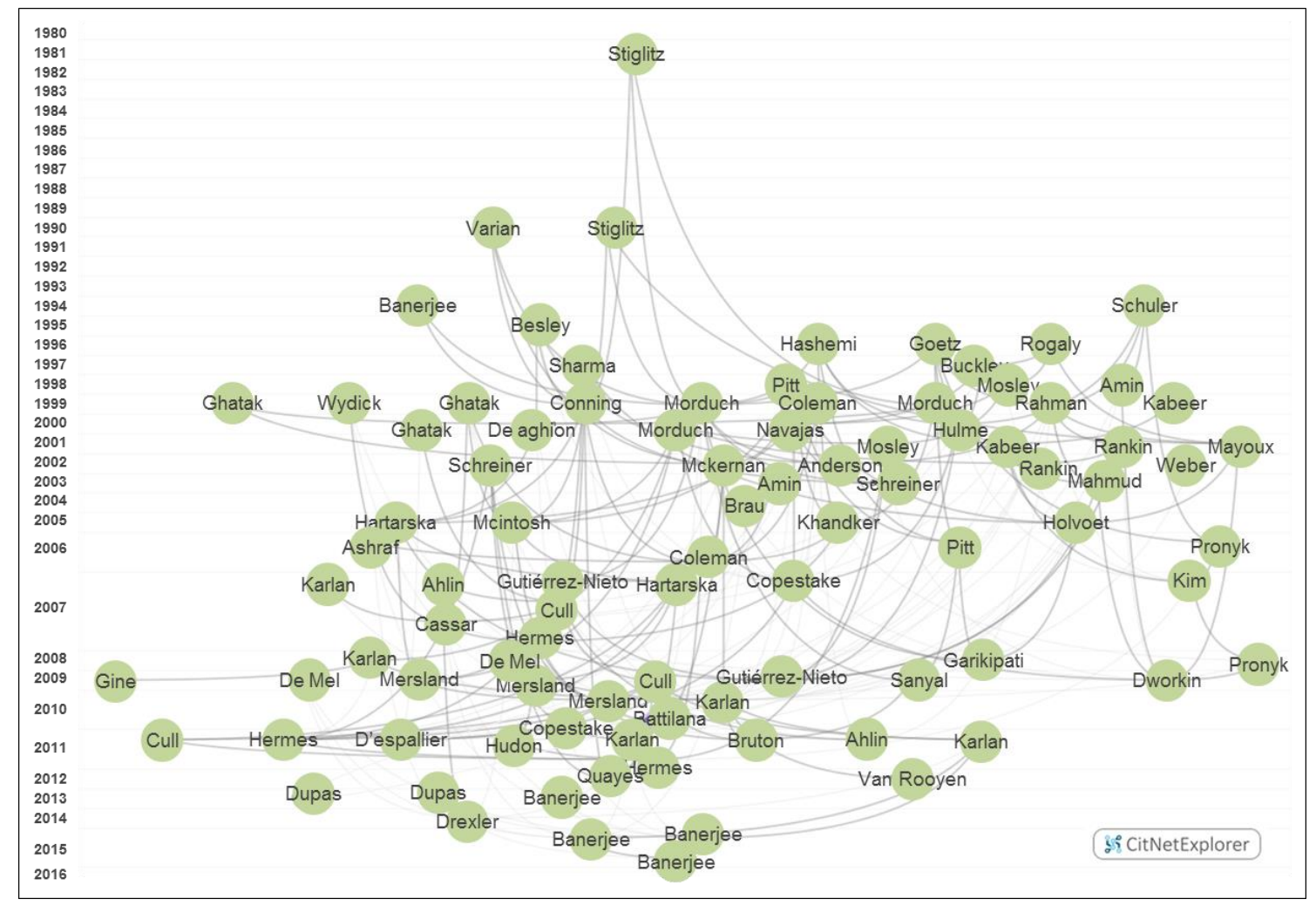

Figure 2. CitNetExplorer visualization of the most frequently cited publications by the microfinance researchers and their citation relations. Only the last name of the first author is shown. 


\begin{tabular}{|c|c|c|c|c|c|}
\hline Paper & Journal & $\begin{array}{l}\text { Citations from } \\
\text { microfinance } \\
\text { researchers / } \\
\text { (ranking) } \\
\end{array}$ & $\begin{array}{c}\text { Citations } \\
\text { from Google } \\
\text { Scholar / } \\
\text { (ranking) } \\
\end{array}$ & $\begin{array}{c}\text { Citations } \\
\text { from Web } \\
\text { of Science / } \\
\text { (ranking) } \\
\end{array}$ & $\begin{array}{c}\text { Exclusivity } \\
\text { ratio }\end{array}$ \\
\hline Ahlin et al. (2011) & Journal of Development Economics & $88 /(19)$ & $387 /(59)$ & $97 /(47)$ & $90.72 \%$ \\
\hline Amin et al. (1998) & Journal of Developing Areas & $35 /(86)$ & $261 /(83)$ & $53 /(90)$ & $66.04 \%$ \\
\hline Amin et al. (2003) & Journal of Development Economics & $38 /(78)$ & $541 /(40)$ & $85 /(60)$ & $44.71 \%$ \\
\hline Anderson et al. (2002) & World Development & $35 /(86)$ & $310 /(74)$ & $74 /(71)$ & $47.30 \%$ \\
\hline Banerjee et al. (1994) & Quarterly Journal of Economics & $60 /(39)$ & $851 /(20)$ & $150 /(25)$ & $40.00 \%$ \\
\hline Banerjee et al. (2013) & Science & 45 / (69) & $688 /(29)$ & $145 /(30)$ & $31.03 \%$ \\
\hline Banerjee et al. (2015a) & American Economic Journal: Applied Economics & $62 /(36)$ & $1573 /(9)$ & $97 /(47)$ & $63.92 \%$ \\
\hline Banerjee et al. (2015b) & Science & $32 /(93)$ & $326 /(70)$ & $81 /(65)$ & $39.51 \%$ \\
\hline Banerjee et al. (2015c) & American Economic Journal: Applied Economics & $51 /(58)$ & $386 /(60)$ & $83 /(63)$ & $61.45 \%$ \\
\hline Battilana and Dorado (2010) & Academy of Management Journal & $70 /(27)$ & $1449 /(11)$ & $552 /(3)$ & $12.68 \%$ \\
\hline Cassar et al. (2007) & Economic Journal & $44 /(71)$ & $300 /(76)$ & $81 /(65)$ & $54.32 \%$ \\
\hline Coleman (1999) & Journal of Development Economics & $85 /(20)$ & $689 /(28)$ & $147 /(28)$ & $57.82 \%$ \\
\hline Coleman (2006) & World Development & $46 /(65)$ & $515 /(43)$ & $86 /(59)$ & $53.49 \%$ \\
\hline Conning (1999) & Journal of Development Economics & $76 /(23)$ & $542 /(39)$ & $105 /(39)$ & $72.38 \%$ \\
\hline Copestake (2007) & World Development & $55 /(46)$ & $369 /(64)$ & $88 /(55)$ & $62.50 \%$ \\
\hline Copestake et al. (2001) & Journal of Development Studies & $37 /(79)$ & $313 /(73)$ & $63 /(82)$ & $58.73 \%$ \\
\hline Cull et al. (2007) & Economic Journal & $155 /(4)$ & $803 /(21)$ & $195 /(19)$ & $79.49 \%$ \\
\hline Cull et al. (2009) & Journal of Economic Perspectives & $146 /(5)$ & $727 /(25)$ & $189 /(21)$ & $77.25 \%$ \\
\hline Cull et al. (2011) & World Development & $62 /(36)$ & $291 /(79)$ & $70 /(74)$ & $88.57 \%$ \\
\hline D'espallier et al. (2011) & World Development & $81 /(21)$ & $287 /(80)$ & $99 /(46)$ & $81.82 \%$ \\
\hline De Mel et al. (2008) & Quarterly Journal of Economics & $64 /(33)$ & $895 /(17)$ & $261 /(13)$ & $24.52 \%$ \\
\hline De Mel et al. (2009) & Journal of Development Economics & $32 /(93)$ & $304 /(75)$ & $87 /(57)$ & $36.78 \%$ \\
\hline Drexler et al. (2014) & American Economic Journal: Applied Economics & $37 /(79)$ & $368 /(65)$ & $54 /(89)$ & $68.52 \%$ \\
\hline Godquin (2004) & World Development & $43 /(73)$ & $325 /(71)$ & $69 /(77)$ & $62.32 \%$ \\
\hline Goetz \& Gupta (1996) & World Development & $187 /(3)$ & $1800 /(5)$ & $393 /(7)$ & $47.58 \%$ \\
\hline Gutiérrez-Nieto et al. (2007) & Omega & $63 /(34)$ & $329 /(69)$ & $79 /(68)$ & $79.75 \%$ \\
\hline Gutiérrez-Nieto et al. (2009) & Journal of the Operational Research Society & $54 /(51)$ & $232 /(87)$ & $62 /(84)$ & $87.10 \%$ \\
\hline Hartarska \& Nadolnyak (2007) & Applied Economics & $80 /(22)$ & $389 /(58)$ & $100 /(43)$ & $80.00 \%$ \\
\hline Hartarska (2005) & World Development & $76 /(23)$ & $477 /(51)$ & $104 /(40)$ & $73.08 \%$ \\
\hline Hashemi et al. (1996) & World Development & $135 /(10)$ & $1574 /(8)$ & $322 /(9)$ & $41.93 \%$ \\
\hline Hermes \& Lensink (2007) & Economic Journal & $75 /(26)$ & $478 /(50)$ & $97 /(47)$ & $77.32 \%$ \\
\hline Hermes \& Lensink (2011) & World Development & $60 /(39)$ & $298 /(77)$ & 77 / (70) & $77.92 \%$ \\
\hline Hermes et al. (2011) & World Development & $127 /(12)$ & $558 /(34)$ & $148 /(27)$ & $85.81 \%$ \\
\hline Holvoet (2005) & Development and Change & $44 /(71)$ & $297 /(78)$ & $87 /(57)$ & $50.57 \%$ \\
\hline Hudon \& Traca (2011) & World Development & $56 /(44)$ & $148 /(93)$ & $64 /(81)$ & $87.50 \%$ \\
\hline Hulme (2000) & World Development & $49 /(61)$ & $657 /(31)$ & $91 /(54)$ & $53.85 \%$ \\
\hline Kabeer (1999) & Development and Change & $49 /(61)$ & $2550 /(3)$ & $726 /(1)$ & $6.75 \%$ \\
\hline Kabeer (2001) & World Development & $137 /(8)$ & $1106 /(14)$ & $283 /(12)$ & $48.41 \%$ \\
\hline Karlan \& Valdivia (2011) & Review of Economics and Statistics & $49 /(61)$ & $749 /(24)$ & $147 /(28)$ & $33.33 \%$ \\
\hline Karlan (2007) & Economic Journal & $60 /(39)$ & $557 /(35)$ & $132 /(32)$ & $45.45 \%$ \\
\hline Karlan and Zinman (2008) & American Economic Review & $36 /(81)$ & $256 /(85)$ & $70 /(74)$ & $51.43 \%$ \\
\hline Karlan and Zinman (2010) & Review of Financial Studies & $70 /(27)$ & $699 /(27)$ & $125 /(36)$ & $56.00 \%$ \\
\hline Karlan and Zinman (2011) & Science & $55 /(46)$ & $318 /(72)$ & $93 /(53)$ & $59.14 \%$ \\
\hline Khandker (2005) & World Bank Economic Review & $146 /(5)$ & $1475 /(10)$ & $223 /(15)$ & $65.47 \%$ \\
\hline Kim et al. (2007) & American Journal of Public Health & $66 /(32)$ & $501 /(46)$ & $217 /(18)$ & $30.41 \%$ \\
\hline Mahmud (2003) & Development and Change & $36 /(81)$ & $261 /(83)$ & $58 /(85)$ & $62.07 \%$ \\
\hline Matin \& Hulme (2003) & World Development & 33 / (91) & $262 /(82)$ & $65 /(79)$ & $50.77 \%$ \\
\hline Mayoux (2001) & Development and Change & $53 /(54)$ & $607 /(32)$ & $150 /(25)$ & $35.33 \%$ \\
\hline
\end{tabular}


McIntosh \& Wydick (2005) McKernan (2002)

Mersland \& Strøm (2009)

Mersland \& Strøm (2010)

Mersland (2009)

Morduch (1999a)

Morduch (1999b)

Morduch (2000)

Mosley (2001)

Mosley \& Hulme (1998)

Navajas et al. (2000)

Pitt \& Khandker (1998)

Pitt et al. (2006)

Pronyk et al. (2006)

Pronyk et al. (2008)

Quayes (2012)

Rahman (1999)

Rankin (2001)

Rankin (2002)

Rogaly (1996)

Sanyal (2009)

Schreiner (2002)

Schreiner \& Woller (2003)

Schuler \& Hashemi (1994)

Sharma \& Zeller (1997)

Stiglitz \& Weiss (1981)

Stiglitz (1990)

Van Rooyen et al. (2012)

Varian (1990)

Weber (2002)

Wydick (1999)
Journal of Development Economics

Review of Economics and Statistics

Journal of Banking \& Finance

World Development

World Development

Journal of Economic Literature

Journal of Development Economics

World Development

Journal of Development Studies

World Development

World Development

Journal of Political Economy

Economic Development and Cultural Change

Lancet

AIDS

Applied Economics

World Development

Economy and Society

Feminist Economics

Development in Practice

American Sociological Review

Journal of International Development

World Development

Studies in Family Planning

World Development

American Economic Review

World Bank Economic Review

World Development

Journal of Institutional and Theoretical Economics

Review of International Studies

Economic Journal

\begin{tabular}{cccc}
$76 /(23)$ & $385 /(62)$ & $100 /(43)$ & $76.00 \%$ \\
$36 /(81)$ & $340 /(68)$ & $65 /(79)$ & $55.38 \%$ \\
$106 /(16)$ & $557 /(35)$ & $129 /(35)$ & $82.17 \%$ \\
$108 /(15)$ & $495 /(48)$ & $130 /(34)$ & $83.08 \%$ \\
$47 /(64)$ & $174 /(90)$ & $55 /(88)$ & $85.45 \%$ \\
$266 /(1)$ & $3095 /(2)$ & $531 /(4)$ & $50.09 \%$ \\
$61 /(38)$ & $495 /(48)$ & $85 /(60)$ & $71.76 \%$ \\
$133 /(11)$ & $1353 /(12)$ & $219 /(17)$ & $60.73 \%$ \\
$43 /(73)$ & $386 /(60)$ & $63 /(82)$ & $68.25 \%$ \\
$41 /(75)$ & $532 /(41)$ & $73 /(73)$ & $56.16 \%$ \\
$57 /(43)$ & $727 /(25)$ & $95 /(51)$ & $60.00 \%$ \\
$197 /(2)$ & $1798 /(6)$ & $397 /(6)$ & $49.62 \%$ \\
$58 /(42)$ & $451 /(54)$ & $102 /(42)$ & $56.86 \%$ \\
$70 /(27)$ & $780 /(23)$ & $442 /(5)$ & $15.84 \%$ \\
$52 /(56)$ & $233 /(86)$ & $131 /(33)$ & $39.69 \%$ \\
$46 /(65)$ & $161 /(92)$ & $48 /(91)$ & $95.83 \%$ \\
$103 /(17)$ & $999 /(16)$ & $194 /(20)$ & $53.09 \%$ \\
$67 /(30)$ & $523 /(42)$ & $220 /(16)$ & $30.45 \%$ \\
$56 /(44)$ & $544 /(38)$ & $144 /(31)$ & $38.89 \%$ \\
$45 /(69)$ & $375 /(63)$ & $\mathrm{n} . \mathrm{a}$. & $\mathrm{n} . \mathrm{a}$. \\
$50 /(59)$ & $226 /(88)$ & $83 /(63)$ & $60.24 \%$ \\
$55 /(46)$ & $467 /(53)$ & $\mathrm{n} . \mathrm{a}$. & $\mathrm{n} . \mathrm{a}$. \\
$34 /(90)$ & $214 /(89)$ & $56 /(87)$ & $60.71 \%$ \\
$46 /(65)$ & $554 /(37)$ & $157 /(24)$ & $29.30 \%$ \\
$63 /(34)$ & $422 /(56)$ & $103 /(41)$ & $61.17 \%$ \\
$115 /(14)$ & $17780 /(1)$ & $665.4 /(2)$ & $17.28 \%$ \\
$142 /(7)$ & $1923 /(4)$ & $355 /(8)$ & $40.00 \%$ \\
$55 /(46)$ & $268 /(81)$ & $79 /(68)$ & $69.62 \%$ \\
$54 /(51)$ & $855 /(19)$ & $181 /(23)$ & $29.83 \%$ \\
$35 /(86)$ & $471 /(52)$ & $58 /(85)$ & $60.34 \%$ \\
$53 /(54)$ & $402 /(57)$ & $97 /(47)$ & $54.64 \%$ \\
\hline & & & \\
& & & \\
$53)$ & &
\end{tabular}

Table 1. The top 5\% of influential papers written by microfinance researchers. The exclusivity ratio measures the percentage of citations received from the core set to citations from the Web of Science. 

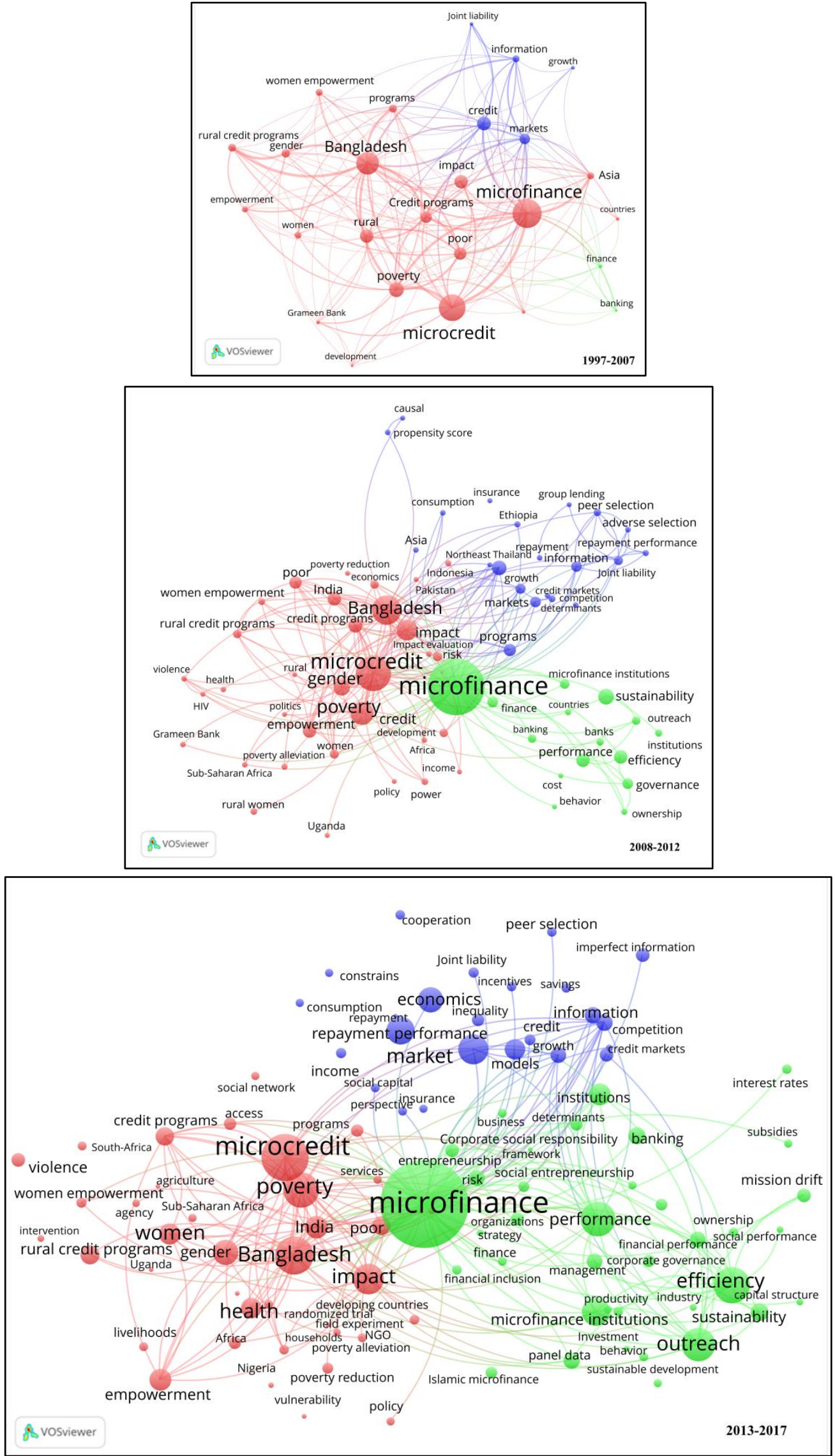

Figure 3. Knowledge maps obtained from keyword co-occurrence analysis. At the top, the first stage, 1997-2007. In the middle, 2008-2012. At the bottom, 2013-1017. Institutionalism is shown in green color, welfarism in red color and generalism in blue color. 


\begin{tabular}{|c|c|c|c|c|c|}
\hline \multicolumn{2}{|c|}{ Years 1997-2007 } & \multicolumn{2}{|c|}{ Years 2008-2012 } & \multicolumn{2}{|c|}{ Years 2013-2017 } \\
\hline Topics & Occurrences/(\%) & Topics & Occurrences/(\%) & Topics & Occurrences/(\%) \\
\hline poverty & $28 / 18.4 \%$ & poverty & $83 / 16.9 \%$ & women & $199 / 17.1 \%$ \\
\hline rural & $26 / 17.0 \%$ & women & $79 / 16.1 \%$ & poverty & $160 / 13.7 \%$ \\
\hline women & $15 / 9.8 \%$ & impact & $49 / 10.0 \%$ & performance & $141 / 12.1 \%$ \\
\hline social & $11 / 7.2 \%$ & rural & $48 / 9.8 \%$ & impact & $94 / 8.1 \%$ \\
\hline group lending & $9 / 5.9 \%$ & development & $35 / 7.1 \%$ & development & $80 / 6.9 \%$ \\
\hline health & $7 / 4.6 \%$ & health & $21 / 4.3 \%$ & social & $75 / 6.4 \%$ \\
\hline housing & $7 / 5.2 \%$ & performance & $34 / 6.9 \%$ & outreach & $73 / 6.3 \%$ \\
\hline food & $6 / 4.4 \%$ & sustainability & $23 / 4.9 \%$ & efficiency & $63 / 5.4 \%$ \\
\hline microenterprise & $6 / 4.4 \%$ & social & $18 / 3.7 \%$ & rural & $52 / 4.5 \%$ \\
\hline Grameen Bank & $6 / 4.4 \%$ & group lending & $19 / 3.9 \%$ & sustainability & $45 / 3.9 \%$ \\
\hline impact & $7 / 4.6 \%$ & efficiency & $18 / 3.7 \%$ & entrepreneur & $40 / 3.4 \%$ \\
\hline banking & $5 / 3.5 \%$ & governance & $16 / 3.3 \%$ & Islamic finance & $40 / 3.4 \%$ \\
\hline development & $5 / 3.5 \%$ & housing & $13 / 2.7 \%$ & health & $40 / 3.4 \%$ \\
\hline informal finance & $3 / 2.6 \%$ & outreach & $12 / 2.4 \%$ & financial inclusion & $28 / 2.4 \%$ \\
\hline cost-benefit analysis & $3 / 2.6 \%$ & financial markets & $10 / 2.2 \%$ & housing & $18 / 1.5 \%$ \\
\hline credit risk & $3 / 2.0 \%$ & microenterprise & $10 / 2.0 \%$ & mission drift & $18 / 1.5 \%$ \\
\hline Asia & $45 / 60.3 \%$ & Asia & $90 / 51.7 \%$ & Asia & $159 / 60.9 \%$ \\
\hline Africa & $13 / 17.8 \%$ & Africa & $26 / 25.9 \%$ & Africa & $60 / 23.0 \%$ \\
\hline Latin America & $9 / 12.5 \%$ & Latin America & $45 / 14.9 \%$ & Latin America & $33 / 12.6 \%$ \\
\hline Rest of the world & $7 / 9.4 \%$ & Rest of the world & $13 / 7.5 \%$ & Rest of the world & $9 / 3.4 \%$ \\
\hline
\end{tabular}

Table 2. Top twenty topics by number of occurrences. To calculate them, synonym keywords were replaced using a thesaurus. In bold, the emerging topics in each stage. 


\begin{tabular}{rrrr}
\cline { 2 - 4 } & \multicolumn{3}{c}{ Publications' percentage } \\
\hline & $1997-2007$ & $2008-2012$ & $2013-2017$ \\
\hline Welfarism & $51.64 \%$ & $44.35 \%$ & $34.25 \%$ \\
Institutionalism & $20.32 \%$ & $31.12 \%$ & $36.55 \%$ \\
Generalism & $28.04 \%$ & $24.53 \%$ & $29.20 \%$ \\
& \multicolumn{3}{|}{} \\
\cline { 2 - 4 } & Impact according to received citations \\
\hline Welfarism & $1997-2007$ & $2008-2012$ & $2013-2017$ \\
\hline Institutionalism & $49.56 \%$ & $43.12 \%$ & $35.12 \%$ \\
Generalism & $22.35 \%$ & $33.16 \%$ & $36.25 \%$ \\
\hline
\end{tabular}

Table 3. Evolution of welfarism vs. institutionalism vs. generalism, according to the number of papers and their impact, measured by the citations each received. 


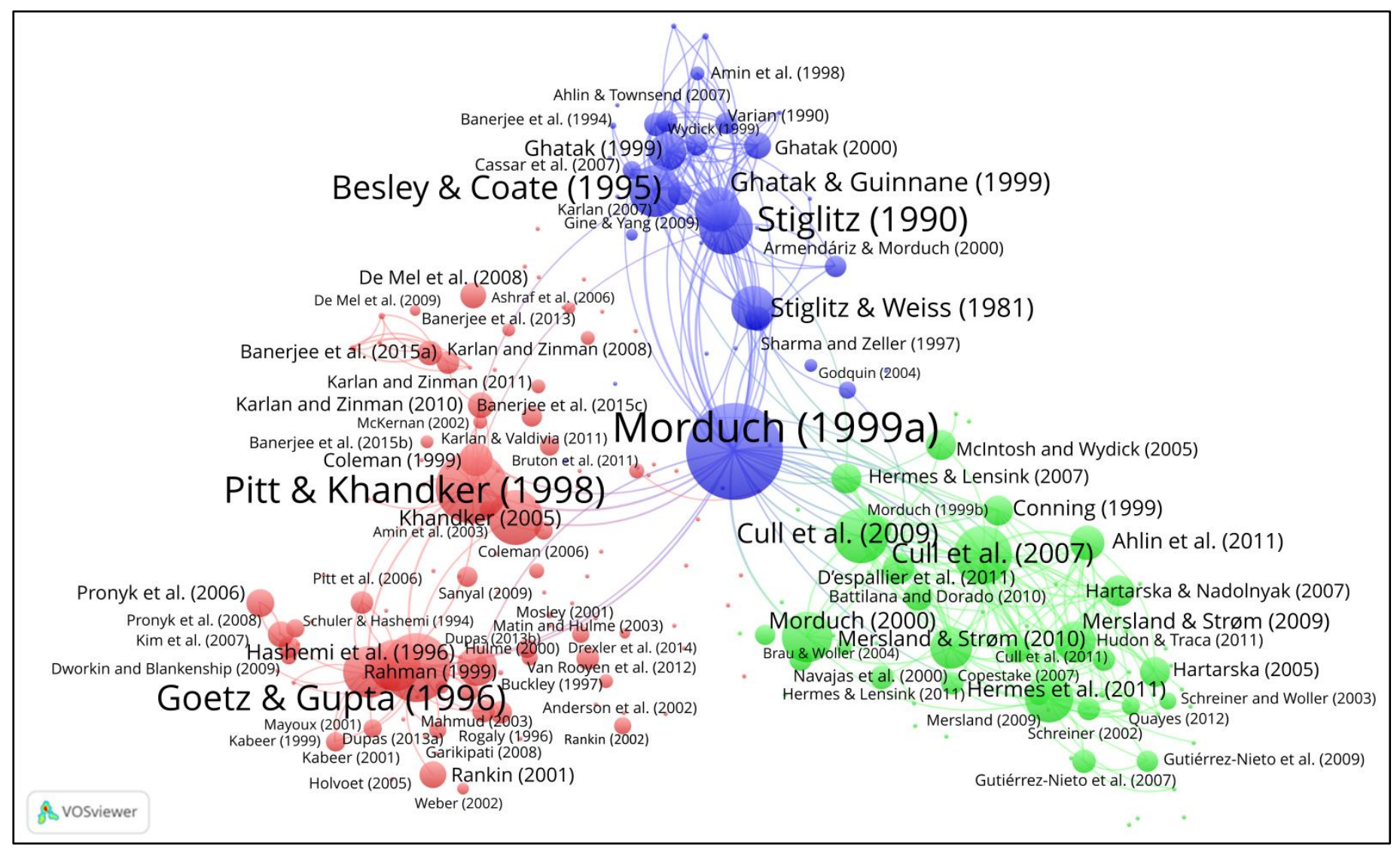

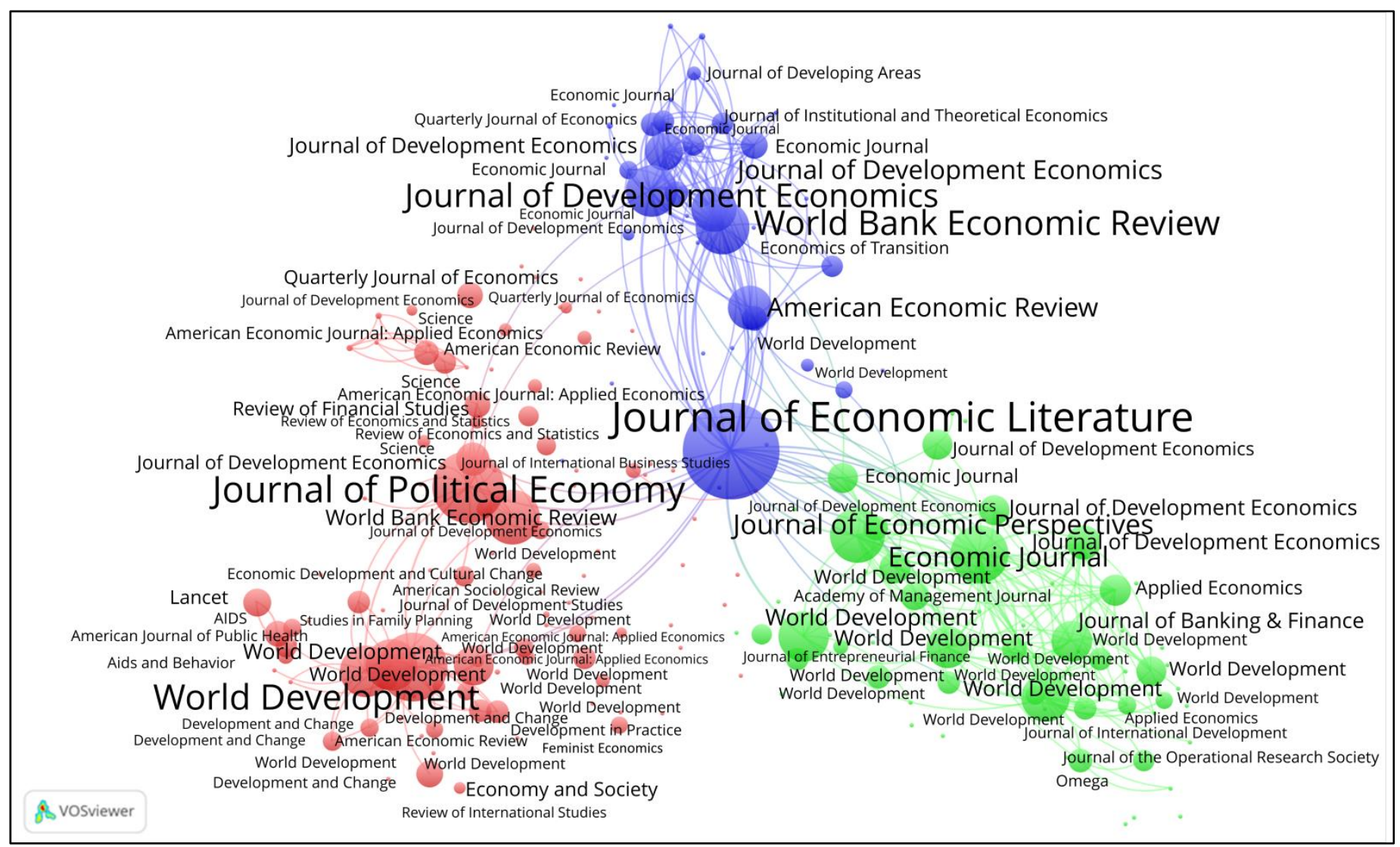

Figure 4. Knowledge maps obtained from co-citation analysis of microfinance publications. At the top, the authors and publication date. At the bottom, the journals' names. Institutionalism is shown in green color, welfarism in red color and generalism in blue color. 


\begin{tabular}{rcccc}
\multicolumn{1}{c}{ Keyword } & $\begin{array}{c}\text { Average } \\
\text { Publication Year }\end{array}$ & $\begin{array}{c}\text { Number of } \\
\text { Occurrences }\end{array}$ & $\begin{array}{c}\text { Average } \\
\text { citations }\end{array}$ & $\begin{array}{c}\text { Normalized } \\
\text { citations }\end{array}$ \\
\hline financial inclusion & 2016.5 & 26 & 2.7 & 0.9 \\
Islamic microfinance & 2016.1 & 27 & 0.8 & 0.3 \\
randomized controlled-trial & 2015.6 & 16 & 5.3 & 1.9 \\
social entrepreneurship & 2015.4 & 19 & 8.0 & 3.4 \\
social networks & 2015.5 & 15 & 8.1 & 1.6 \\
panel-data & 2015.5 & 36 & 3.5 & 0.9 \\
mission drift & 2015.4 & 24 & 10.6 & 1.9 \\
outreach & 2015.4 & 112 & 8.9 & 1.7 \\
efficiency & 2015.3 & 95 & 8.2 & 1.6 \\
sustainability & 2015.2 & 66 & 7.4 & 1.4 \\
impact & 2014.2 & 172 & 9.0 & 1.6 \\
microfinance & 2013.9 & 534 & 8.8 & 1.1 \\
microcredit & 2013.6 & 213 & 7.9 & 1.0 \\
empowerment & 2013.5 & 98 & 8.4 & 1.1 \\
social capital & 2013.3 & 27 & 32.0 & 2.0 \\
poverty & 2013.1 & 223 & 13.0 & 1.2 \\
group lending & 2011.8 & 15 & 14.0 & 0.9 \\
Grameen Bank & 2010.1 & 48 & 14.9 & 1.1 \\
rural credit programs & 2009.1 & 23 & 21.9 & 1.5 \\
\hline
\end{tabular}

Table 4. Microfinance research trends from keyword analyses. 